\title{
Invited review: Microbiota of the bovine udder: Contributing factors and potential implications for udder health and mastitis susceptibility
}

\author{
Hooman Derakhshani, ${ }^{*}$ Kelsey B. Fehr, ${ }^{*}$ Shadi Sepehri, † David Francoz,‡ Jeroen De Buck,§ \\ Herman W. Barkema, $§$ Jan C. Plaizier, ${ }^{*}$ and Ehsan Khafipour*\# ${ }^{1}$ \\ *Department of Animal Science, University of Manitoba, Winnipeg, MB, R3T 2N2 Canada \\ †Children Hospital Research Institute of Manitoba, Winnipeg, MB, R3E 3P4 Canada \\ ‡Département de Sciences Cliniques, Faculté de Médecine Vétérinaire, Université de Montréal, Montréal, QC, J2S 2M2 Canada \\ $\S$ Department of Production Animal Health, Faculty of Veterinary Medicine, University of Calgary, Calgary, AB, T2N 4N1 Canada \\ \#Department of Medical Microbiology and Infectious Diseases, University of Manitoba, Winnipeg, MB, R3E 0J9 Canada
}

\begin{abstract}
Various body sites of vertebrates provide stable and nutrient-rich ecosystems for a diverse range of commensal, opportunistic, and pathogenic microorganisms to thrive. The collective genomes of these microbial symbionts (the microbiome) provide host animals with several advantages, including metabolism of indigestible carbohydrates, biosynthesis of vitamins, and modulation of innate and adaptive immune systems. In the context of the bovine udder, however, the relationship between cow and microbes has been traditionally viewed strictly from the perspective of host-pathogen interactions, with intramammary infections by mastitis pathogens triggering inflammatory responses (i.e., mastitis) that are often detrimental to mammary tissues and cow physiology. This traditional view has been challenged by recent metagenomic studies indicating that mammary secretions of clinically healthy quarters can harbor genomic markers of diverse bacterial groups, the vast majority of which have not been associated with mastitis. These observations have given rise to the concept of "commensal mammary microbiota," the ecological properties of which can have important implications for understanding the pathogenesis of mastitis and offer opportunities for development of novel prophylactic or therapeutic products (or both) as alternatives to antimicrobials. Studies conducted to date have suggested that an optimum diversity of mammary microbiota is associated with immune homeostasis, whereas the microbiota of mastitic quarters, or those with a history of mastitis, are considerably less diverse. Whether disruption of the diversity of udder microbiota (dysbiosis) has a role in determining mastitis susceptibility remains unknown. Moreover, little is
\end{abstract}

Received April 2, 2018.

Accepted August 5, 2018.

${ }^{1}$ Corresponding author: Ehsan.Khafipour@umanitoba.ca known about contributions of various biotic and abiotic factors in shaping overall diversity of udder microbiota. This review summarizes current understanding of the microbiota within various niches of the udder and highlights the need to view the microbiota of the teat apex, teat canal, and mammary secretions as interconnected niches of a highly dynamic microbial ecosystem. In addition, host-associated factors, including physiological and anatomical parameters, as well as genetic traits that may affect the udder microbiota are briefly discussed. Finally, current understanding of the effect of antimicrobials on the composition of intramammary microbiota is discussed, highlighting the resilience of udder microbiota to exogenous perturbants.

Key words: bovine, mastitis, udder microbiota, teat canal

\section{INTRODUCTION}

Mammalian colostrum and milk not only serve as complete nutrient sources for offspring, but also contain a complex array of bioactive molecules capable of modulating intestinal immune homeostasis of newborns, preparing for a microbe-rich extrauterine environment (Morrow and Rangel, 2004; Stelwagen et al., 2009). Immunoglobulins, lysozyme, lactoferrin, antimicrobial peptides, and oligosaccharides are some of the immunoregulatory components of milk (Gill et al., 2000; Korhonen et al., 2000; Newburg, 2005; Tao et al., 2009) capable of targeting and deactivating pathogens individually, additively, and synergistically (Isaacs, 2005). In addition to supporting the immature innate immune response of neonates, these immunoregulatory compounds can also act as important components of the defense mechanism of the udder itself and protect it against IMI by pathogenic and opportunistic microorganisms (Oviedo-Boyso et al., 2007). This is an essential property for mammals, as their intramammary ecosystem, due to the availability of a wide range of 
nutrients and optimum temperature, is an ideal environment for growth of bacteria (Stelwagen et al., 2009).

The teat canal (TC), owing to its complex biochemical and structural characteristics, can be an effective barrier against the entry of environmental microorganisms into the udder (Paulrud, 2005). However, certain conditions (e.g., prepartal loss of the keratin plug of the $\mathrm{TC}$ or postmilking dilation of the sphincter muscle of the TC) can compromise this first-line defense mechanism of the udder and increase susceptibility to invasion and colonization by a wide range of microorganisms from various extramammary sources (Paulrud, 2005; Jones and Bailey, 2009). Once invasive microorganisms, particularly bacteria, breach the TC and gain access to the teat cistern of the udder, despite the presence of robust innate and acquired immune responses (Sordillo and Streicher, 2002), the intramammary ecosystem seems to provide them a permissive environment to thrive. This can be evidenced by the ability of the majority of mastitis pathogens to survive and proliferate within the intramammary ecosystem at a relatively fast pace, despite triggering varying degrees of inflammatory responses (Rainard, 2017). Insights from recent metagenomic investigations of bovine milk microbiota (Addis et al., 2016) suggest that in addition to mastitis pathogens, which usually have a variety of virulence factors that enable them to resist the defense mechanisms of the udder (Barkema et al., 2006; Melchior et al., 2006), a diverse range of opportunistic and commensal bacteria can also inhabit the intramammary ecosystem. However, genetic traits and mechanisms by which commensal bacteria evade or control immune responses of the udder are poorly understood. Lactic acid bacteria isolated from the milk or TC, for example, can adhere to and internalize bovine mammary epithelial cells and modulate production of pro-inflammatory cytokines by these cells (Bouchard et al., 2015). Regardless, emergence of the concept of intramammary microbiota contradicts the traditional view that milk in a healthy udder quarter is sterile (Rainard, 2017). Discrepancies between these 2 concepts can be largely explained by methodological differences between novel DNA sequencing techniques and conventional culturebased approaches. Although metagenomic techniques offer universal coverage of coexisting microbes within a complex ecosystem (Franzosa et al., 2015), conventional culture-based techniques are usually optimized based on growth requirements of certain mastitis pathogens and hence fail to identify other bacterial lineages that have different, sometimes more fastidious, growth requirements. Based on recent developments in microbial culturomics, if proper and extensive culture conditions are provided, most previously "unculturable bacterial species" can be readily isolated from complex microbial ecosystems (Goodman et al., 2011; Lagier et al., 2012; Lau et al., 2016). Being able to isolate representative strains of the vast majority of bacteria detected through parallel sequencing of universal genes, these new methodologies have served as critical tests to validate results of metagenomic studies regarding the immense diversity of microbes that inhabit the gut ecosystem. Unfortunately, such culturomic techniques have not yet been optimized for exploring the uncultured portion of udder microbiota. Nevertheless, high-throughput sequencing of bacterial $16 \mathrm{~S}$ rRNA genes have revealed that colostrum and milk samples obtained from nonmastitic quarters of dairy cows contain genetic markers of diverse bacterial groups that usually go undetected with conventional culture-based techniques (Kuehn et al., 2013; Oikonomou et al., 2014; Lima et al., 2017). These findings do not provide undeniable evidence for viability or functionality (or both) of detected bacterial groups (Rainard, 2017). Nonetheless, they can be an important first step in understanding the complexity of the udder microbial ecosystem and its role in modulating udder homeostasis and mastitis susceptibility. Comprehensive metagenomic and metatranscriptomic investigations are required to develop a holistic understanding of genetic diversity and functionality of various bacterial groups within the udder ecosystem. Moreover, these novel molecular techniques can also provide an exciting opportunity for investigating the role of traditionally neglected components of the udder microbiome, including fungi, protozoa, and viruses, in modulating mastitis susceptibility.

This review provides an overview of the potential origin(s) of intramammary microbiota; our current understanding of various niches of the udder microbial ecosystem including teat apex, TC, milk and colostrum microbiota; host and environmental factors capable of influencing composition of udder microbiota, in particular cows' physiological status, housing conditions, and antimicrobial use; and how microbiota may influence susceptibility of an individual dairy cow to mastitis pathogens.

\section{POTENTIAL ORIGIN(S) OF INTRAMAMMARY MICROBIOTA}

From an ecological perspective, the mammalian body is considered a complex ecosystem (metacommunity) consisting of various, albeit interconnected, ecological niches (i.e., body sites; Costello et al., 2012). Although each ecological niche in the mammalian body harbors distinct and specialized microbiome profiles, interplay among various body sites makes colonization and assembly of their microbiota far from an isolated process (Costello et al., 2009). In the bovine udder, milk se- 
creted from healthy cells was historically thought to be sterile (Tolle, 1980), and therefore, colonization of internal niches of the udder, more specifically milk, with microbial communities, has been traditionally considered as an IMI that occurs upon transgression of environmental microbial contaminants past the TC (Paulrud, 2005). This traditional view has been challenged by recent reports supporting the existence of an entero-mammary pathway in humans and mice through which live bacteria can be transferred from intestines to the mammary gland (reviewed by Rodríguez, 2014). This hypothetical endogenous pathway proposes that upon internalization of live bacteria by intestinal dendritic cells (DC) and macrophages, these bacteria can be transferred to the mammary gland via lymphatic and peripheral blood circulation. Although intestinal DC and macrophages usually degrade engulfed bacteria before migration to lymphoid tissues such as the spleen and lymph nodes (Banchereau and Steinman, 1998), evidence indicates that DC and CD18-expressing phagocytes can alternatively retain and translocate limited number of live intestinal bacteria to lymphoid tissues (Vazquez-Torres et al., 1999; Rescigno et al., 2001; Macpherson and Uhr, 2004). In ruminants, however, the link between the immune system of the udder and intestinal immune system is very poor, and the majority of lymphocytes providing local immunity originate from peripheral lymph nodes rather than mucosal sites such as intestines (Kehrli and Harp, 2001). Hematogenous and lymphatic translocations have been suggested as potential endogenous routes by which certain pathogens (e.g., Mycoplasma bovis and Mycobacterium avium ssp. paratuberculosis) can cause IMI (Sweeney, 1996; Fox et al., 2005). However, it should be noted that simultaneous detection of referred pathogens in milk, body tissues, and lymphatic nodes (Sweeney et al., 1992; Streeter et al., 1995; Biddle et al., 2005) does not conclusively prove that IMI with these bacterial groups are caused by endogenous translocation, rather than breaching the TC from extramammary sites. Similarly, concurrent detection of certain gut-associated bacteria in feces, milk somatic cells and blood leukocytes of healthy cows (Young et al., 2015) does not prove there is an endogenous route for migration of intestinal microbiota to the udder. Gut-associated bacteria are omnipresent in the dairy environment, and therefore IMI through environmental sources (e.g., bedding materials) are a more likely source for circulating lymphocytes containing these bacteria. Nonetheless, these findings warrant further investigations for identification of potential mechanisms for entero-mammary pathways in ruminants, which could open new doors to applications of alternative therapies for mastitis (i.e., ingested probiotics). Oral administration of probiotic Lactobacillus strains, including L. fermentum CECT5716, L. salivarius CECT5713, and L. gasseri CECT5714, has proven to be more effective in treatment of infectious mastitis in humans than administration of antibiotics (Jiménez et al., 2008; Arroyo et al., 2010). Indeed, detection of aforementioned probiotic strains in the milk of treated patients following oral administration provided further evidence for entero-mammary translocation of live bacteria in humans (Rodríguez, 2014).

Leaving aside the controversy as to whether or not an endogenous route contributes to development of udder microbiota, it is widely accepted that microbial colonization of the teat apex and TC have principal roles in development of IMI. As indicated earlier, prepartal loss of the keratin lining of the TC and postmilking dilation of the teat sphincter can compromise the barrier function of the TC and increase the risk of IMI by environmental microbes (Dingwell et al., 2004; Krömker and Friedrich, 2009). Consequently, composition and functionality of microbial communities that colonize the teat apex, teat orifice, and TC lining could influence intramammary microbial colonization and, as a result, modulate udder health status. This has been exemplified by several studies (Haveri et al., 2008; Taponen et al., 2008; Quirk et al., 2012) indicating that microbial colonization of the TC with certain staphylococcal species can serve as an important reservoir for development of new IMI. In addition, comparative analyses of microbiota profiles of milk, teat skin, feces, and bedding materials have also suggested that teat skin is the most important source of milk microbiota, with the microbiota of herd feces and bedding material being the next most prevalent sources of intramammary microbiota (Doyle et al., 2016; Fehr et al., 2017). These findings underscore the important contribution of the microbiota of various niches of the udder, particularly teat skin and the $\mathrm{TC}$, as well as various environmental sources (e.g., bedding material and milking equipment), in shaping the intramammary microbiota.

\section{MICROBIOTA COMPOSITION OF VARIOUS NICHES OF THE UDDER}

\section{Teat Apex Microbiota}

To date, a combination of culture-dependent and DNA-based approaches (Woodward et al., 1987; Braem et al., 2012; Verdier-Metz et al., 2012) have been deployed to explore diversity of bacterial communities colonizing the teat apex of dairy cows. These studies have revealed a wide diversity of commensal, pathogen, and skin-associated opportunistic bacteria from 4 major bacterial phyla, namely Actinobacteria, Bacteroidetes, Firmicutes, and Proteobacteria, can reside on the skin 
of the teat apex of dairy cows. The most commonly identified genera include Acinetobacter, Aerococcus, Corynebacterium, Enterobacter, Facklamia, Lactobacillus, Lactococcus, Micrococcus, Propionibacterium, Staphylococcus, and Streptococcus, among which nonaureus staphylococci (NAS) have gained the greatest attention. The NAS species, previously referred to as CNS, are omnipresent in the dairy environment and considered the leading cause of IMI (Pyörälä and Taponen, 2009; De Visscher et al., 2014; Vanderhaeghen et al., 2014). Staphylococcus chromogenes, followed by Staphylococcus simulans, Staphylococcus xylosus, Staphylococcus haemolyticus, and Staphylococcus epidermidis, are the NAS species most frequently isolated from cow milk (Vanderhaeghen et al., 2014; Condas et al., 2017a). These species have contradictory behavior with respect to udder homeostasis (Pyörälä and Taponen, 2009; Vanderhaeghen et al., 2014), whereas some are detrimental to udder health (i.e., resulting in clinical or subclinical mastitis; Thorberg et al., 2009; Supré et al., 2011; Condas et al., 2017b), others confer protection against IMI with major mastitis pathogens (Matthews et al., 1990; De Vliegher et al., 2004). Indeed, the ability of some NAS species (e.g., Staph. chromogenes) to produce a wide range of bacteriocins capable to inhibit the growth of major mastitis pathogens (Braem et al., 2014; Carson et al., 2017) is a good example of mechanisms by which commensal microbiota may contribute to the modulation of mastitis susceptibility. Other than NAS, Acinetobacter, Aerococcus, and Corynebacterium are among the most frequently identified genera on the skin of teat apices (Braem et al., 2012). Acinetobacter and Aerococcus are normal colonizers of human skin (Grice et al., 2010; Fyhrquist et al., 2014), but their association with udder health and IMI are barely understood. Corynebacteria consist of a large number of species that are frequently detected in cow milk and are usually associated with low SCC IMI (Quigley et al., 2013; Oikonomou et al., 2014). Similar to NAS, Corynebacterium spp. also have contradictory functionalities with regard to conferring protection against IMI with major mastitis pathogens (Woodward et al., 1987; Hogan et al., 1988).

\section{Teat Canal Microbiota}

Due to methodological difficulties of aseptic TC sampling under farm conditions, only a few studies have investigated global diversity of the microbiota of this niche of the udder (Gill et al., 2006; Falentin et al., 2016). From these studies, it appears that Staphylococcus spp., in particular NAS species, are among the most prevalent colonizers of TC microbiota, even when cows are subjected to pre- and postmilking teat disinfection. Gut-associated bacteria, including Clostridiaceae and Lachnospiraceae, were identified as predominant members of the TC microbiota when cows were housed in freestall/tiestall arrangements (Gill et al., 2006). Corynebacterium, Ruminococcus, Aerococcus, Bifidobacterium, and Facklamia were other prevalent bacterial genera within the microbiota of teat cistern and TC of healthy cows kept in indoor freestall barns (Falentin et al., 2016). In the latter study, TC microbiota of cows with a history of clinical mastitis (CM) contained higher proportions of bacilli compared with healthy cows, and the proportion of this bacterial order was positively correlated with proportion of NAS. Conversely, clostridia and Bifidobacterium were proportionally higher in healthy (i.e., nonmastitic) quarters, leading the authors to hypothesize that the bacilli to clostridia ratio could have a role in determining udder health. Another interesting finding of this study was lower diversity of TC microbiota of quarters with a history of CM compared with healthy quarters. Insights obtained through the Human Microbiome Project indicated that exogenous perturbants, such as antimicrobials, can reduce diversity of bodily microbial ecosystems and enter them into alternative stable states with reduced species richness and diversity (Lozupone et al., 2012). The resilience of the postantibiotic state of commensal microbiota to invasion by exogenous pathogens and overgrowth of endogenous opportunists can determine susceptibility to new infections or recurrence of previous ones (Lozupone et al., 2012). In the context of the bovine udder, however, it is not yet determined whether the postantibiotic state of commensal microbiota is associated with increased susceptibility to IMI (Figure 1).

\section{Milk and Colostrum Microbiota}

Due to their importance to the dairy industry and animal welfare, the epidemiology and pathogenesis of major mastitis pathogens, such as Staphylococcus aureus, Streptococcus dysgalactiae, Streptococcus uberis, Streptococcus agalactiae, Klebsiella spp., and Escherichia coli, have been widely investigated. These investigations have implemented a wide range of culture-dependent or molecular techniques (or both), which have been optimized for qualitative and quantitative analyses of these major mastitis pathogens in milk samples obtained from healthy and mastitic quarters (Zadoks et al., 2011). To date, however, only a few studies have used high-throughput sequencing technologies to determine global diversity of milk microbiota in relation to udder health and disease (Bhatt et al., 2012; Oikonomou et al., 2012, 2014; Kuehn et al., 2013; Ganda et al., 2016, 2017; Bonsaglia et al., 2017; Derakhshani et 


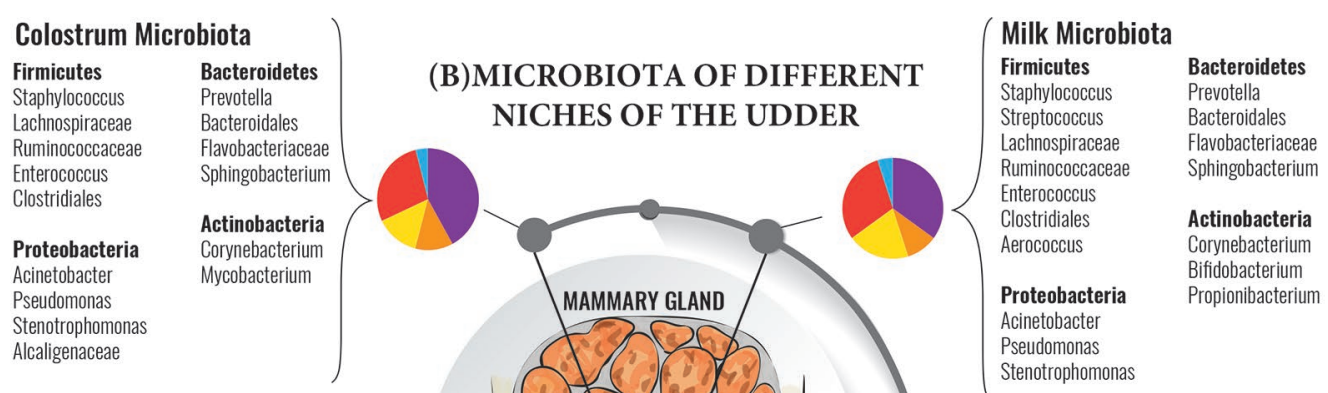

(A) POTENTIAL SOURCES OF MAMMARY MICROBIOTA

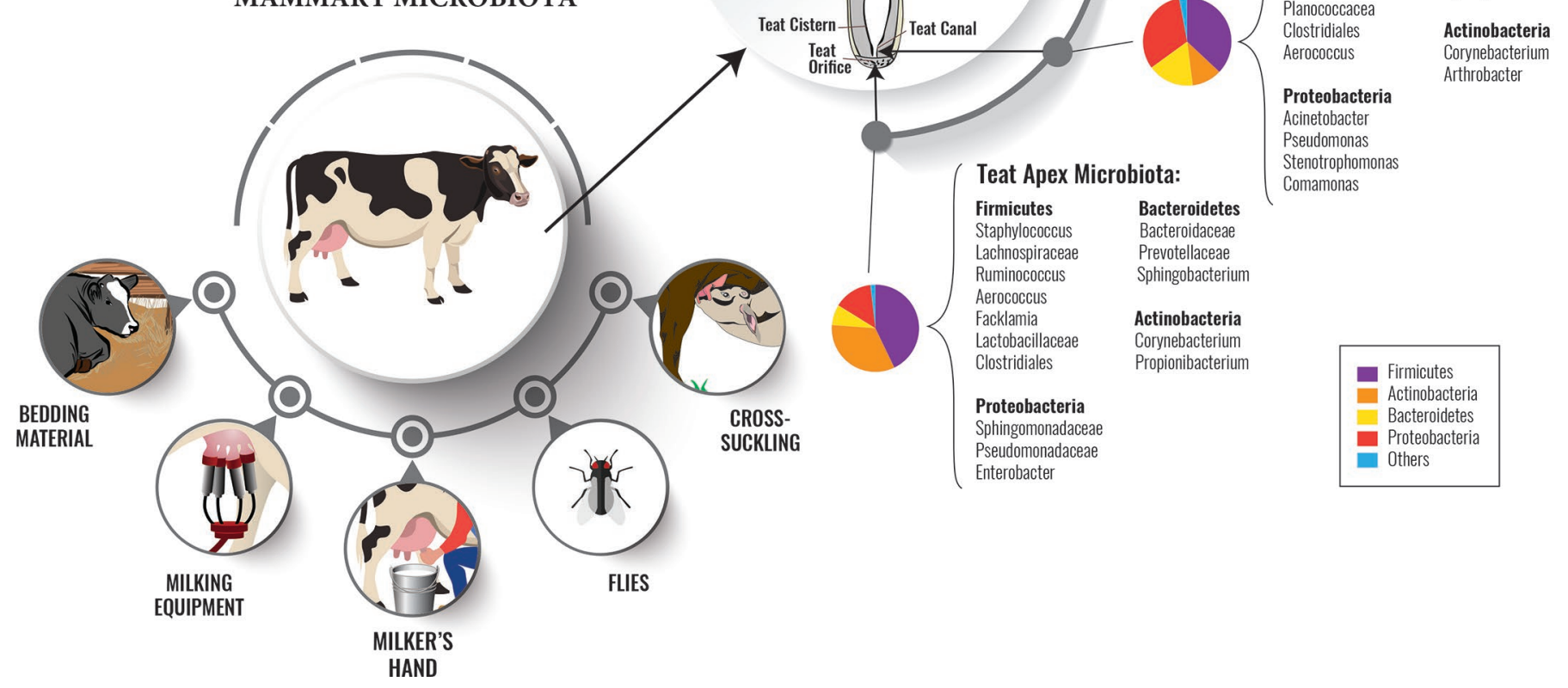

Figure 1. Potential sources and composition of udder microbiota. (A) Environmental sources of microbes contributing to microbiota of various niches of the udder. (B) Microbiota composition of various niches of the udder. Proportions of main bacterial phyla were estimated based on studies that used 16S rRNA gene sequencing to explore udder microbiota. Color version available online.

al., 2017a; Lima et al., 2017). Overall, based on these studies, we inferred that regardless of the inflammatory status of the udder, and whether or not a quarter is diagnosed as having CM, intramammary secretions (i.e., colostrum or milk) can harbor far more diverse bacterial communities than traditionally thought. Similar to microbiota of the teat apex and TC, Firmicutes, Proteobacteria, Bacteroidetes, and Actinobacteria are main bacterial phyla shaping the structure of milk microbiota. Staphylococcus, Ruminococcaceae, Lachnospiraceae, Propionibacterium, Stenotrophomonas, Corynebacterium, Pseudomonas, Streptococcus, Comamonas, Bacteroides, Enterococcus, Lactobacillus, and Fusobacterium are the most frequently detected bacterial taxa within the microbiota of milk samples obtained from clinically healthy quarters (Bhatt et al., 2012; Kuehn et al., 2013; Oikonomou et al., 2014; Ganda et al., 2016, 2017; Bonsaglia et al., 2017). Staphylococcus, Prevotella, Ruminococcaceae, Bacteroidales, Clostridiales, and Pseudomonas have also been identified as predominant constituents of healthy colostrum microbiota (Lima et al., 2017).

Although the microbial profile of milk samples obtained from healthy quarters has not always been consistent among referred studies, a common finding has been the association of mastitis with dysbiotic microbiota, based on differences in microbial composition ( $\beta$-diversity) and/or richness and evenness ( $\alpha$-diversity) when comparing milk from mastitic quarters to healthy quarters. For example, comparison of the microbiota of milk samples from clinically healthy quarters and those from culture-negative mastitic quarters revealed that 
the latter group contained higher proportions of genera Burkholderia, Sphingomonas, and Stenotrophomonas, whereas genera Pseudomonas, Psychrobacter, and Ralstonia were overrepresented in the microbiota of healthy quarters (Kuehn et al., 2013). Alternatively, milk microbiota of clinically affected quarters was less speciesrich and diverse compared with those obtained from healthy quarters (Oikonomou et al., 2014). In the latter study, genera Sphingobacterium and Streptococcus had a positive correlation with SCC, whereas Nocardiodes and Paenibacillus were negatively correlated with udder inflammation, suggesting potential contributions of these genera to maintaining mammary homeostasis. An unexpected finding of this study was detection of sequences belonging to Strep. uberis in both healthy and mastitis milk samples. Streptococcus uberis has long been considered a major environmental pathogen able to provoke udder inflammation and cause (sub) clinical mastitis (Leigh, 1999; Bradley, 2002). Detection of this bacterium within the microbiota of healthy quarters led the authors to suggest that some strains of this bacterium may be normal constituents of milk microbiota and therefore CM caused by them may be sometimes as a result of microbial dysbiosis rather than a primary infection (Oikonomou et al., 2014). Other examples of mastitis-associated dysbiosis were changes in composition of milk microbiota in response to naturally occurring (Ganda et al., 2016) or experimental (Ganda et al., 2017) IMI with pathogenic strains of E. coli. Under both circumstances, members of the family Enterobacteriaceae proportionally dominated the microbiota of infected quarters shortly after infection. Congruent with temporary shifts in milk SCC, Enterobacteriaceae dominance spontaneously resolved a few days after infection, and the microbiota of infected quarters became as diverse as uninfected ones, even in the absence of antimicrobial therapy. Microbiota dysbiosis may also be a potential predisposing factor for IMI by mastitis pathogens. The colostrum microbiota of quarters that developed CM during the first month postpartum were markedly less diverse than the colostrum microbiota of quarters that remained healthy throughout early lactation (Lima et al., 2017).

\section{HOST AND ENVIRONMENTAL FACTORS WITH POTENTIAL TO AFFECT UDDER MICROBIOTA}

Defense mechanisms of the udder against microbial colonization are modulated by several host-associated and environmental factors including, but not limited to the following: cows' genotype in particular genes encoding various components of the innate and adaptive immune systems (Heringstad et al., 2000; Rupp and Boichard, 2003), changes in cows' physiological status and metabolic profile during different stages of lactation cycle (Leslie et al., 2000; Barkema et al., 2006; Goff, 2006), and implementation of mastitis control practices such as antimicrobial dry cow therapy, postmilking teat disinfection, and milking hygiene (Barkema et al., 1999; Green et al., 2007). Due to the important role that each of the above-mentioned factors has in modulating immune homeostasis of the udder and resistance to IMI, it can be postulated that they also have direct/indirect influence on the composition of udder microbiota (Figure 2).

\section{Candidate Genes Associated with Mastitis Susceptibility and IMI}

A main approach for identification of genetic markers for mastitis susceptibility is to focus on genetic variations within candidate genes of interest, most importantly those associated with systemic and local immune responsiveness of the udder against mastitis pathogens (Pighetti and Elliott, 2011). Direct or indirect associations with antigen recognition, leukocyte recruitment, and pathogen elimination are the most important functional criteria, based on which the majority of candidate genes have been selected and screened for associations with mastitis susceptibility (Detilleux, 2009). Particularly, genes encoding the major histocompatibility complex (MHC) molecules, also known as bovine leukocyte antigens (BoLA), have gained increasing attention due to their critical roles in modulation of innate and acquired immune responses (Rupp and Boichard, 2003). Furthermore, selection of phenotypic traits that can be used as direct or indirect measures of mastitis susceptibility is also an important component of genetic marker discovery protocols. Despite being an indirect measure of mastitis, SCC is one of the most useful and widely accepted traits for assessment of mastitis susceptibility (Heringstad et al., 2000). Indeed, SCC measurement has several advantages over direct phenotypic traits (i.e., CM records), namely (1) ease of measurement and low cost, as SCC is routinely recorded in DHI programs and is available on a much larger scale than records of CM; (2) high genetic correlation between SCC and CM (usually $>70 \%$ ); and (3) slightly higher heritability coefficient of SCC (0.05-0.25) compared with CM (usually <0.10; Detilleux, 2009; Pighetti and Elliott, 2011). Therefore, along with CM records, SCC has been the most widely investigated phenotypic trait for evaluating associations of candidate genes of interest with mastitis susceptibility (Heringstad et al., 2000).

Structure and Function of BoLA-DRB3 Genes. The class II region of the BoLA gene is located within 2 distinct regions of chromosome 23 and consists of 2 subregions, specifically class IIa with functionally 


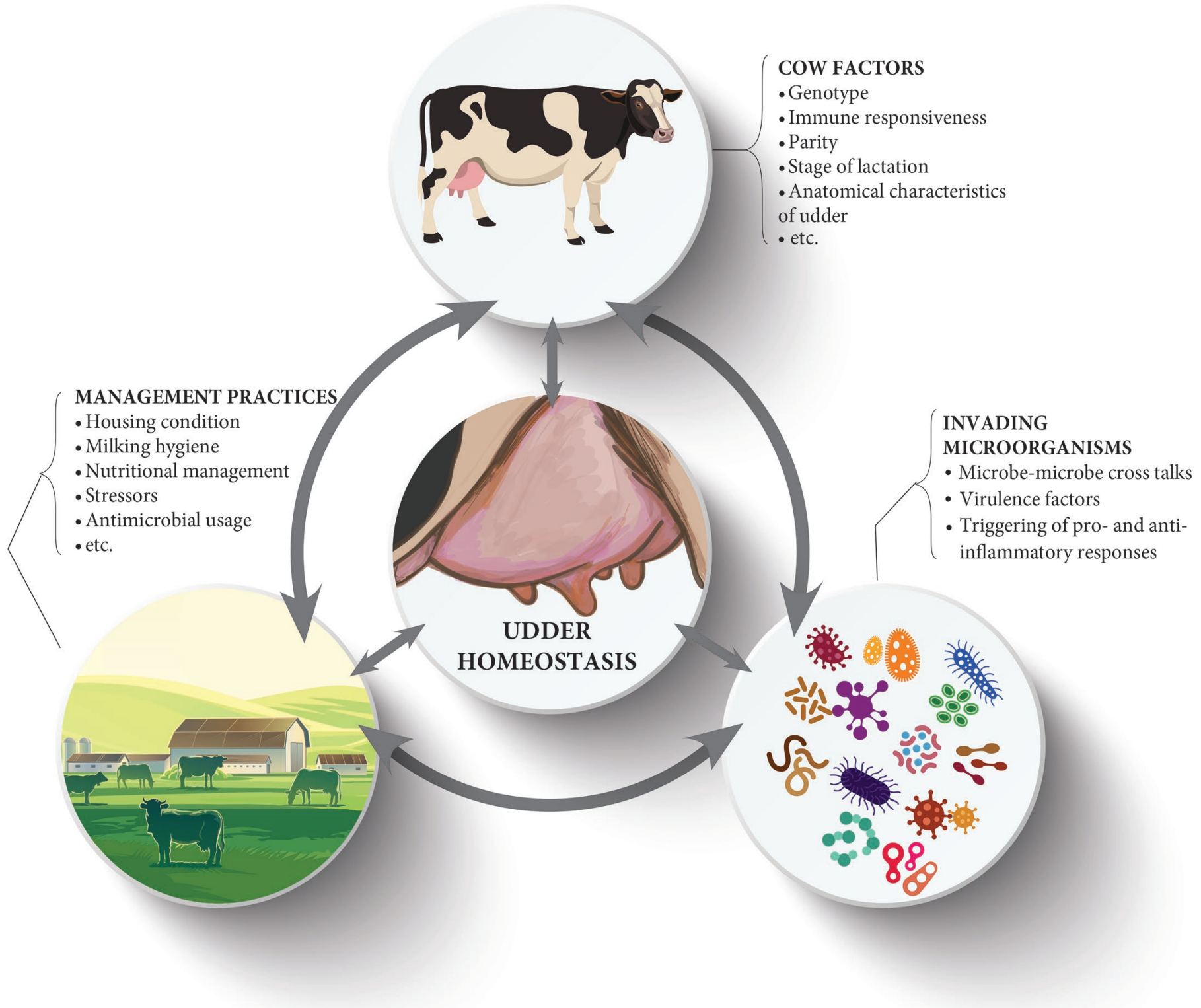

Figure 2. Determinants of udder homeostasis. Defense mechanisms of the udder against microbial colonization are modulated by a complex interaction network among (A) cow genotype, physiological status, and udder characteristics; (B) invading microorganisms, their cross talks, and virulence factors; and (C) management practices that can influence metabolic and immune homeostasis of the cow. Color version available online.

expressed $D R$ and $D Q$ genes, and class IIb, which is currently uncharacterized (Takeshima and Aida, 2006). The BoLA-DR subregion of cattle consists of a single, usually nonpolymorphic $D R A$ locus and at least 3 $D R B$ loci (DRB1-3), with only one of them, the $D R B 3$ gene, being fully expressed and functionally important (Takeshima and Aida, 2006). The BoLA class II genes are responsible for encoding highly polymorphic glycoprotein molecules on the surface of antigen presenting cells (APC) including macrophages, DC, and B lymphocytes (Takeshima and Aida, 2006). The main function of these MHC class II molecules is to facilitate the role of APC in discriminating between "self " and "non-self" antigens: upon internalization of exogenous antigens by APC (via phagocytosis or endonucleosis), these antigens are degraded into smaller peptides and bound to MHC class II molecules. The MHC class IIantigen complex on the surface of the APC will then be presented to $\mathrm{CD} 4+$ helper $\mathrm{T}$ lymphocytes and trigger complex cellular and humoral immune responses against non-self antigens of exogenous infectious agents (Sordillo, 2005).

Associations Between BoLA-DRB3 Alleles and Mastitis Susceptibility. As indicated in the 
previous section, the $B o L A-D R B 3$ gene has a critical role in various aspects of immune responsiveness of the udder, including recognition of exogenous antigens and leukocyte recruitment, and consequently, elimination of infectious agents. Therefore, potential associations between allelic variations of this gene and phenotypic traits of mastitis have been the focus of much research (Rupp and Boichard, 2003; Takeshima and Aida, 2006; Behl et al., 2012). Polymorphic variations of this gene family are largely located within exon 2 , named $B o L A$ DRB3.2 (Hameed et al., 2006; Takeshima and Aida, 2006). The most widely used technique for studying polymorphism of the BoLA-DRB3.2 has been PCRRFLP, using restriction enzymes RsaI, HaeIII, and BstYI, followed by PAGE of resulting products (van Eijk et al., 1992). To date, more than 130 BoLA-DRB3 alleles have been identified in various breeds of cattle with their nomenclature/sequence information on the website of the Immuno Polymorphism Database (http: //www.ebi.ac.uk/cgi-bin/ipd/mhc/view_nomenclature .cgi?bola.drb3). Several studies have reported the frequency of BoLA-DRB3.2 alleles in various breeds of cattle and evaluated their associations with SCC or susceptibility/resistance to $\mathrm{CM}$ by major pathogens (Behl et al., 2012). Frequencies of BoLA-DRB3.2 alleles (RFLP haplotypes) appear to be breed dependent. For example, the most frequently detected alleles in Canadian Holsteins were BoLA DRB3.2*3, *8, *11, *16, *22, *23, and *24 (Sharif et al., 1998; Rupp et al., 2007), whereas in Japanese Shorthorns BoLA DRB3.2*8, *9, $*_{21}$, 27 , *7, and $*_{24}$ were identified as predominant alleles (Takeshima et al., 2002). Associations of these alleles with SCC and mastitis susceptibility have not been consistent among studies. For instance, BoLA DRB3.2*16 has been reported to be associated with high (Dietz et al., 1997; Kelm et al., 1997) or low (Starkenburg et al., 1997; Sharif et al., 1998) milk SCC. Similarly, BoLA DRB3.2*23 has been reported to be associated with increased (Kelm et al., 1997) or decreased resistance to CM (Sharif et al., 1998). One possible explanation for inconsistencies among abovementioned studies is that cows' susceptibility to IMI can be modulated by multiple genes, differing based on the causative pathogens, and the collective contribution of these genes to determining phenotypic traits of mastitis may outweigh the effect of BoLA-DRB3.2 (Pighetti and Elliott, 2011).

Potential Links Between MHC Genes and Commensal Microbiota. Studies in humans (De Palma et al., 2010), mice (Toivanen et al., 2001; Kubinak et al., 2015), and fish (Bolnick et al., 2014) have demonstrated that polymorphism of the MHC genotype can influence composition of commensal microbiota along the gastrointestinal tract (GIT). Microbiome-MHC interactions have also been investigated in the context of disease susceptibility, suggesting that certain MHC class II genotypes can increase resistance to Salmonellainduced enteric infection in mice (Kubinak et al., 2015). In this latter study, microbiota transplantation from mice with resistant MHC genotypes to recipients with susceptible genotypes increased resistance of the latter group to oral challenge with Salmonella typhimurium, without changing the profile of their immune response. Consequently, the authors speculated that unique profiles of microbiota formed in mice with resistant MHC genotypes can affect host susceptibility to disease, independent of the immune response, suggesting a potential mechanism of underlying MHC-mediated patterns of disease susceptibility. In a recent study, polymorphism of the BoLA DRB3.2 was associated with distinct microbiota profiles in colostrum samples collected immediately postcalving (Derakhshani et al., 2017b). In this study, each of the identified BoLA-DRB3.2 haplotypes $(\mathrm{n}=3)$ was associated with enrichment of specific operational taxonomic units within colostrum microbiota, with the most notable differences for certain NAS species, namely Staph. chromogenes, Staph. sciuri, and Staph. succinus. As indicated earlier, the role of NAS species in modulating udder homeostasis is controversial, with some species considered the most important causes of subclinical mastitis during the periparturient period, whereas others are reported to protect the udder against invasion by major mastitis pathogens. These observations may be indicative of a potentially indirect mechanism by which MHC genes contribute to modulation of udder homeostasis via modulation of intramammary microbiota. This hypothesis warrants further mechanistic investigations of links among BoLA gene polymorphisms, immunomodulatory components of humoral and cellular immunity, and microbiota of various niches of the udder in large cohort studies.

\section{Periparturient Immunosuppression}

Defense mechanisms of the udder undergo considerable changes throughout lactation (Sordillo and Streicher, 2002). The periparturient period, usually defined as the period from approximately 3 wk before calving to $3 \mathrm{wk}$ after calving, is the most critical stage of the production cycle of cows with respect to udder health (Oliver and Sordillo, 1988). During this interval, several aspects of the innate and adaptive immune systems, such as the barrier function of the TC and recruitment and phagocytic activities of leukocytes, become compromised and as a result cows become susceptible to IMI by both environmental and contagious mastitis pathogens (Pyörälä, 2008). The TC is considered the first line of defense of the udder against the 
entry of microbes from extramammary sites (e.g., skin of the teat apex, milking machine, bedding material, and so on) into the udder (Paulrud, 2005; Jones and Bailey, 2009). Sphincter muscles of the TC are responsible for maintaining tight closure of the TC between milkings, preventing microbial penetration into the udder. In addition, the keratin lining of the $\mathrm{TC}$ also provides biochemical and anatomical barriers against microbial migration into the udder (Paulrud, 2005). During the dry period, the keratin lining has a principal role in occluding the TC duct and preventing IMI by environmental microorganisms. However, as calving approaches, accumulation of large amounts of intramammary secretions (mostly via colostrogenesis) results in increased intramammary pressure, dilation of the TC, and leakage of intramammary secretions. Collectively, these compromise the anatomical barrier of the TC and pose a greater risk of IMI (Sordillo and Streicher, 2002). Meanwhile, various aspects of the innate and adaptive immune systems also become compromised (Pyörälä, 2008). Polymorphonuclear neutrophils (PMN) are considered the most important components of innate immunity during early stages of udder inflammation. As the main responders of the udder immune system to bacterial infections, PMN travel from blood to the udder to engulf and kill bacteria via various mechanisms, including production of reactive oxygen species (ROS) and secretion of small bactericidal peptides such as defensins (Persson et al., 1993; Selsted et al., 1993). However, during the periparturient period, elevated blood glucocorticoid concentrations reduce expression of adhesion molecules (L-selectin) on the surface of PMN (Weber et al., 2004), impairing their ability to migrate from the endothelium of blood vessels to intramammary sites of infection (Monfardini et al., 2002). Concurrently, other important functions of neutrophils, including phagocytic activity and production of ROS, also become impaired (Sordillo and Streicher, 2002).

Another important component of innate immunity are macrophages, whose primary role is to initiate and facilitate innate and acquired immune responses of the udder by releasing cytokines, leukotrienes, and other immunomodulatory molecules. In addition, similar to neutrophils, macrophages also contribute to elimination of invading pathogens by phagocytosis and secretion of ROS (Sordillo, 2005; Rainard and Riollet, 2006). However, during the periparturient period, the phagocytic activity of the udder macrophages also decreases. This functional impairment may be partly explained by reduced concentrations of certain immunoglobulins (i.e., IgM) and their opsonizing activity in periparturient mammary secretions (Detilleux et al., 1995; Sordillo, 2005). Another critical function of udder macrophages that becomes impaired during the periparturient period is expression of the MHC class II molecules; consequently, their ability to present exogenous antigens to CD4+ T lymphocytes is impaired. This can, in turn, impair main activities of both cell-mediated and humoral (acquired) immune responses, including production of soluble factors such as cytokines, complements, and immunoglobulins (Sordillo, 2005). Immunoglobulins, the principal soluble components of the acquired immune response, are produced by specific B lymphocytes (i.e., plasma cells) following formation of MHC class II-antigen complex. In the bovine udder, the principal immunoglobulins responsible for opsonization of invading bacteria and complement fixation are $\operatorname{IgG}$ $\left(\operatorname{Ig} G_{1}\right.$ and $\left.\operatorname{Ig} G_{2}\right)$, and to a lesser extent, IgM and $\operatorname{IgA}$. Periparturient decreases in intramammary and serum concentrations of these immunoglobulins, in particular $\mathrm{IgG}_{2}$, can increase susceptibility to IMI and mastitis (Mallard et al., 1998).

\section{Metabolic Profile: Reflection of Nutritional Management on Udder Homeostasis}

During the last few decades, an emphasis on genetic selection for maximizing milk production has exposed periparturient cows to major physiological challenges that can compromise their metabolic profile and immune responsiveness (Sordillo and Streicher, 2002; Waller, 2002). During the periparturient period, the nutrient supply and DMI of dairy cows and heifers lags behind their energy requirements for body maintenance, udder involution, fetal growth, colostrogenesis, and milk production (Grummer et al., 2004). This unavoidable state of negative energy balance (NEB) results in development of various metabolic disorders and consequently an impaired immune system (Esposito et al., 2014). For example, NEB-associated hypoglycemia results in increased mobilization of fatty acids from adipose tissue, which can in turn increase the blood concentrations of nonesterified fatty acids (NEFA) and glycerol (Suriyasathaporn et al., 2000). Under normal conditions, when the animal is not experiencing NEB, NEFA are translocated into hepatocytes and subsequently oxidized to NADH and acetyl-CoA, which are required for oxidative phosphorylation and ATP production. However, excessive oxidation of NEFA during the periparturient period results in accumulation of acetyl-CoA and upregulation of an alternative pathway that results in biosynthesis of ketone bodies such as acetoacetate, BHB, and acetone (Duffield, 2000; Suriyasathaporn et al., 2000). Increased blood concentrations of NEFA and ketone bodies have been associated with impairment of key immune functions including phagocytic activity and ROS production of macrophages and neutrophils, recruitment of neutrophils and their translocation from 
endothelium, secretion of inflammatory cytokines, production of complement factors and acute phase proteins by hepatocytes, activation of adaptive immune system, and secretion of immunoglobulins (Leslie et al., 2000; Zerbe et al., 2000; Esposito et al., 2014). It is noteworthy to mention that PMN, macrophages, and lymphocytes prefer glucose as the main source of energy rather than fatty acids or ketone bodies (Ingvartsen and Moyes, 2013). Therefore, periparturient immunosuppression can be largely due to inefficient glucose uptake by immune cells as a result of NEB-associated hypoglycemia and the state of insulin resistance that normally occurs during late pregnancy and early lactation to shift glucose supply from skeletal muscle and adipose tissues to uterus and udder (De Koster and Opsomer, 2013; Ingvartsen and Moyes, 2013).

Although adverse consequences of NEB on bovine immune responsiveness are relatively well characterized, little is known about potential influences of periparturient metabolic disorders on the composition of udder microbiota. Subacute ruminal acidosis, a metabolic disorder attributed to dysbiosis of rumen and hindgut microbiota during adaptation to high-grain lactation diets (Khafipour et al., 2009b), has been linked to enrichment of pathogenic and opportunistic bacterial groups, including Stenotrophomonas, Streptococcus, Pseudomonas, and Alcaligenes, in the milk microbiota of primiparous cows during early lactation (Zhang et al., 2015). Inductions of systemic and local inflammatory responses are potential mechanisms by which SARA can regulate immune homeostasis of the udder. It has been suggested that during SARA, increased shedding and accumulation of free LPS (immunogenic component of the outer cell membrane of gram-negative bacteria) in the GIT of ruminants can trigger a systemic inflammatory response (Plaizier et al., 2008). Indeed, SARA-associated disruption of the epithelial barrier of the GIT accommodates translocation of free LPS from the gut lumen into the blood circulation and the lymphatic system, where it can bind to specific acute phase proteins called LPS-binding proteins (LBP; Khafipour et al., 2009a; Plaizier et al., 2012). The resulting LPS-LBP is an immunomodulatory complex capable of translocating from blood circulation/ lymphatic system to various body sites, including the udder, and modulating local immunity via activation of the NF- $\kappa \mathrm{B}$ pro-inflammatory pathway (Bannerman et al., 2003; Plaizier et al., 2012). However, whether SARA-associated changes in the composition of udder microbiota are a result of the activation of inflammatory immune responses, or perhaps due to translocation of bacteria from the GIT to the udder, remains unanswered and warrants further investigation. Another plausible hypothesis worthy of further investigation with respect to the underlying mechanisms of effects of nutrition on udder microbiota is potential involvement of a microbiome-gut-brain axis (Cryan and O'Mahony, 2011). The interaction between microbiota and the central nervous system is multi-directional, including potential signaling from GIT microbiota to the central nervous system and from the central nervous system to microbiota of various body sites via neural, endocrine, immune, and humoral mechanisms (Carabotti et al., 2015). In ruminants, nutritional challenges during the periparturient period can modulate composition and functionality of GIT microbiota, resulting in altered microbial-driven metabolites along the GIT (Wang et al., 2012; Lima et al., 2015; Derakhshani et al., 2017c). An altered GIT microbiome can in turn affect systemic metabolic profiles (Shabat et al., 2016). As such, changes in the GIT and circulating metabolite profiles may extend far beyond the GIT and affect overall physiology and immune homeostasis, resulting in modulation of microbiota profiles at various body sites. In a recent experimentally induced SARA challenge (Khafipour et al., 2017), we observed concurrent shifts in microbiota profiles of various body sites of periparturient dairy cows, including the udder, GIT, and vagina. Particularly with respect to udder, our correlation network analyses revealed that induction of SARA was associated with enrichment of negative interrelationships among milk microbiota, a common indicator for development of competitive microbial ecosystems (Nemergut et al., 2013).

Apart from metabolic disorders, periparturient deficiency in micronutrients such as trace minerals and vitamins can also affect resistance to IMI in 2 major ways, namely (1) loosening the primary defense line, TC integrity, by impairing the keratin plug or epithelial cell integrity; and (2) compromising leukocyte responses to bacterial infections and changing mechanisms by which phagocytes move to the infection site (Sordillo et al., 1997). Selenium and vitamin E are both important components of the antioxidant defense mechanism (Smith et al., 1997). Vitamin $\mathrm{E}$ is the most important lipid-soluble antioxidant that protects lipid membranes of cells from damage due to high concentrations of ROS (Rice and Kennedy, 1988; Smith et al., 1997). Selenium is an integral component of the enzyme glutathione peroxidase, which has the main function of inactivating ROS within the cytosol of the cell, therefore protecting the body against oxidative stress (Tappel, 1984). Vitamin $\mathrm{E}$ and Se deficiencies have been linked to impaired functionality of PMN (e.g., impaired intracellular killing of internalized pathogens; Smith et al., 1997). Conversely, dietary supplementation with vitamin $\mathrm{E}$ and $\mathrm{Se}$ 
has decreased the incidence of mastitis, shortened the duration of CM, and lowered SCC (Weiss et al., 1990; Smith et al., 1997; Sordillo, 2013). Other important minerals and vitamins with potential contributions to antioxidant defense mechanisms and immune homeostasis of the udder include zinc, copper, vitamin A, and $\beta$-carotene (Spears and Weiss, 2008).

\section{Parity and Stage of Lactation}

Knowledge regarding potential effects of parity and stage of lactation on the overall diversity of the udder microbiota is limited. Lima et al. (2017) reported that the colostrum microbiota of primiparous cows was significantly richer (based on Chao1 estimates of species richness) than that of the multiparous cows, though there was no difference in diversity (Shannon's index) of the 2 microbial communities. In the same study, the proportion of the phylum Firmicutes was considerably higher in colostrum microbiota of primiparous cows, whereas colostrum microbiota of multiparous cows contained a higher proportion of the phylum Fusobacteria. Interestingly, colostrum samples of primiparous cows had a higher proportion of the genus Staphylococcus compared with multiparous cows. Other studies have also reported higher prevalence of Staphylococcus spp. in colostrum and milk of primiparous cows compared with older cows (Matthews et al., 1992; Tenhagen et al., 2006). In fact, susceptibility of dairy cows to IMI by various Staphylococcus spp., in particular NAS, varied based on both parity and stage of lactation. When considered as a single group of bacteria, NAS IMI was more prevalent in heifers than multiparous cows (Pyörälä and Taponen, 2009; Condas et al., 2017a). However, this trend varied among NAS species. In Canadian dairy herds, Staph. chromogenes and Staph. simulans were more prevalent in primiparous cows, whereas Staph. epidermidis, Staph. sciuri, and Staph. gallinarum were more prevalent in multiparous cows (Condas et al., 2017a). With respect to stage of lactation, Staph. chromogenes was reported as the most frequently isolated NAS species throughout lactation, whereas the prevalence of Staph. simulans decreased after 4 mo of lactation. The prevalence of less frequently detected NAS species, such as Staph. haemolyticus and Staph. gallinarum, also decreased after 5 to 10 DIM (Condas et al., 2017a).

Apart from inter-species differences in prevalence of NAS, in general, increasing parity is associated with increased susceptibility to CM (Green et al., 2002; Whist et al., 2006). The prevalence of subclinical mastitis and incidence of $\mathrm{CM}$ in multiparous cows are higher during mid-lactation, whereas in primiparous cows, both incidence and prevalence of CM are higher dur- ing early stages of lactation and usually immediately after calving (Barkema et al., 1998; Green et al., 2007; McDougall et al., 2009). Underlying reasons for associations of IMI with parity and stage of lactation remain poorly understood. Increased susceptibility of multiparous cows to IMI during later stages of lactation, or by increasing parity, may be partly caused by anatomical damage or hyperkeratosis (or both) of the teat end over time (Neijenhuis et al., 2001b; Breen et al., 2009). Agedependent impairment of the immune system may also contribute to increased susceptibility of multiparous cows to IMI (Paganelli et al., 2006; Green et al., 2007; Breen et al., 2009). For instance, PMN in blood and milk of multiparous cows have less efficient phagocytic activity and reduced ROS production compared with neutrophils of primiparous cows (Mehrzad et al., 2002). Carryover of chronic IMI persisting from previous lactations can also be a possible explanation for increased susceptibility of multiparous cows to recurrent mastitis or even development of new IMI.

During early lactation, the changeover from colostrum to transitional and then mature milk is accompanied by considerable shifts in composition of metabolites and immunomodulatory components of mammary secretions (Gopal and Gill, 2000; Stelwagen et al., 2009). Many of these component (e.g., milk oligosaccharides) can affect microbiota composition of mammary secretions and the GIT of newborns consuming these secretions (Addis et al., 2016; Aakko et al., 2017). Longitudinal studies exploring the dynamics of the bovine udder microbiota during various stages of lactation are currently lacking. In humans, comparison of the microbial profile of colostrum and milk collected at 1 and 6 mo postpartum revealed changes in diversity and composition of mammary secretions at various stages of lactation (CabreraRubio et al., 2012). In that regard, microbiota richness of colostrum was considerably higher than those of milk at 1 and 6 mo postpartum. In addition, proportions of genera Weisella, Staphylococcus, Streptococcus, and Lactococcus were higher in colostrum microbiota, whereas proportions of common colonizers of the oral cavity, including genera Veillonella, Leptotrichia, and Prevotella, were enriched in microbiota of 1- and 6-mo milk samples (Cabrera-Rubio et al., 2012). This could be indicative of potential microbial exchange between mammary gland microbiota and microbiota of the infant's oral cavity over time, most likely via retrograde flow of milk from the infant's mouth back into mammary ducts during suckling (Fernández et al., 2013). However, to what extent the composition of the bovine udder microbiota changes among stages of lactation, and potential influence of various extramammary sources of microbiota on dynamics of udder microbiota, are unknown. 


\section{Anatomical Characteristics of the Teat}

Given that the TC is considered the main route by which microbes gain access to the intramammary environment, presumably, anatomical characteristics and integrity of the TC have important roles in shaping composition of intramammary microbiota. Teat-end hyperkeratosis has long been identified as a potential risk factor for development of CM (Neijenhuis et al., 2001a; Zadoks et al., 2001; Bhutto et al., 2010). Hyperkeratosis refers to increased thickness (i.e., callosity) of the stratum corneum (i.e., keratin lining) at the teat end, which usually occurs in response to chronic stimulus (e.g., trauma due to poor milking practices; Neijenhuis et al., 2001a; Breen et al., 2009). Several studies have demonstrated positive associations of teat end hyperkeratosis with higher microbial load and prevalence of IMI (Zadoks et al., 2001; Breen et al., 2009; Paduch et al., 2012). In our recent study evaluating the effect of cows' physiological status and teat end hyperkeratosis on microbiota profiles of the TC and milk (Derakhshani et al., 2017a), we failed to identify a strong association between teat end hyperkeratosis and overall diversity of microbiota at either niches of the udder. Nonetheless, we identified a positive association between teat end hyperkeratosis and proportion of operational taxonomic units belonging to Sphingobacterium, a bacterial genus further associated with future incidences of CM.
This may be indicative of the detrimental effect of teat end hyperkeratosis on the integrity of the TC and its ability to inhibit intramammary colonization by opportunistic/pathogenic bacterial groups.

The sphincter muscles of the TC also have an important role in regulating TC barrier function by blocking leakage of milk and by preventing IMI caused by environmental bacteria (Paulrud, 2005). However, for approximately $1 \mathrm{~h}$ after milking, these sphincter muscles remain dilated, thereby increasing susceptibility to IMI (Neijenhuis et al., 2000; Mein et al., 2004). Several factors such as the inherent diameter of the TC or the shape of the teat end can alter duration of postmilking dilation of the teat sphincter and consequently susceptibility to IMI by environmental microbes (Slettbakk et al., 1995; Chrystal et al., 2001). Prepartum teat edema, which is usually accompanied by leakage of milk, is also considered a risk factor for development of IMI (De Vliegher et al., 2012), and therefore can be considered a contributing factor to shaping udder microbiota during the late stages of pregnancy (Figure 3).

\section{Management Practices with Potential to Affect Udder Microbiota}

Apart from nutritional management of the herd, the most important management practices relevant to udder health are those recommended by the National Mastitis

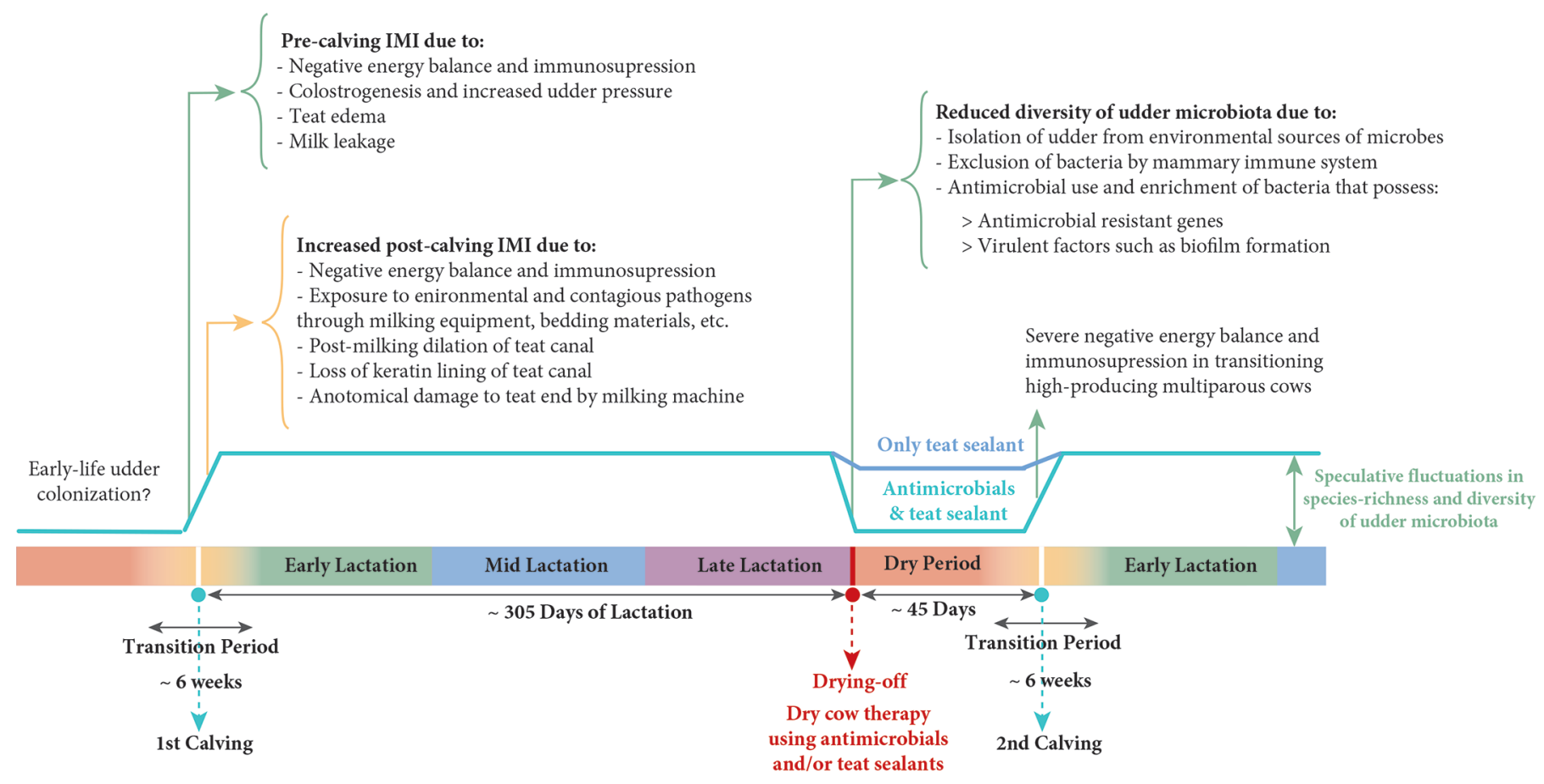

Figure 3. Speculative fluctuations in susceptibility to IMI and diversity of udder microbiota in relation to changes in physiology and environment of the cow before and during the first lactation. Color version available online. 
Council (NMC) under the "10-point Mastitis Control Program" including (1) establishment of realistic goals for improving udder health; (2) maintenance of a clean, dry, and comfortable environment; (3) proper milking procedures; (4) proper maintenance and use of milking equipment; (5) comprehensive herd record-keeping; (6) appropriate management of CM during lactation; (7) effective dry cow management, including implementation of appropriate dry cow treatment (DCT); (8) maintenance of biosecurity measures to control contagious pathogens; (9) regular monitoring of udder health status (e.g., monitoring of SCC, udder cleanliness, teat end hyperkeratosis, and so on); and (10) periodic review of the herd's mastitis control program (Middleton et al., 2014). Although an extensive body of research has used conventional microbiology to explore effects of each of the above-mentioned managerial practices in controlling IMI by major mastitis pathogens, limited knowledge is currently available regarding the potential influence of these practices on the overall composition of udder microbiota.

The housing conditions of dairy cows (indoor vs. pasture) has been reported to have a central role in shaping the composition of udder microbiota, whereas the effect of teat preparation on composition of milk and teat apex microbiota appears to be housing dependent (Doyle et al., 2016). In this study, whereas premilking teat disinfection did not influence milk microbiota of cows housed indoors, during the outdoor grazing season, milk microbiota of cows subjected to premilking teat preparation was more diverse than the nontreated group. In addition, for cows that underwent teat preparation before sampling, the microbiota diversity of teat apex samples was higher during the pasture season compared with the housing season. The milk microbiota of samples collected during the indoor season contained a higher proportion of gut-associated genera such as Ruminococcus, Eremococcus, and Prevotella, whereas the proportion of gram-negative genera such as Pseudomonas and Acinetobacter were higher in the milk microbiota of samples collected during the pasture season. Despite limitations of the above-mentioned study regarding total numbers of cows and farms investigated, these findings provided valuable insights into contributions of environmental factors, particularly housing management and milking hygiene, in shaping the overall udder microbiota.

Bedding management is another important aspect of mastitis control programs that can influence the microbial profile of the cow's environment, and consequently, microbial colonization of the udder (Leach et al., 2015). Similar to other practices related to control of mastitis pathogens, conventional microbiology techniques have been extensively used to explore effects of bedding types on prevalence of major mastitis pathogens on the skin of the teat apex, or to further assess the influence of bedding management on the incidence rate of IMI by mastitis pathogens (Godden et al., 2008; Leach et al., 2015; Rowbotham and Ruegg, 2015). Recently, we compared udder microbiota of cows housed in 3 dairy farms with various bedding materials, including sand, straw, and recovered bedding material. Not surprisingly, compared with all other contributing factors, such as cows' parity and SCC, farm environment, in general, had the greatest effect on the composition of milk microbiota (Fehr et al., 2017). In this study, milk samples collected from the farm using straw bedding material had lower bacterial richness (based on the Chao1 species richness) compared with the other 2 farms. The proportion of the phylum Proteobacteria, the predominant bacterial phyla detected in the milk microbiota across all 3 farms, was also higher in the farm using straw bedding material compared with the other 2 farms. Although in this study we were not able to differentiate the effect of farm bedding material from the effect of other confounding environmental factors on the composition of udder microbiota (e.g., management practices, nutrition, herd size, and so on), we inferred that microbiota of bedding materials may also have a pivotal role in shaping the overall composition of mammary microbiota. In addition, within the farm using straw bedding, both milk and teat-apex swab samples collected during winter contained more species-rich microbiota profiles than samples collected during summer. This observation underscores potential contributions of seasonal factors, such as ambient temperature and humidity, on the composition of microbiota of cows' surrounding environment and consequently udder microbiota.

Overall, based on information in previous sections, the intramammary environment, specifically milk, seems to offer a welcoming ecosystem for a wide range of environmental bacteria. This can be most likely due to the low microbial biomass in intramammary secretions and lack of intense interspecies competition over available nutrients. Compared with the flexible microbiota of intramammary secretions, microbial populations associated with intramammary tissues most likely encounter greater competition over attachment sites/ internalization processes, and therefore may be compositionally more stable in response to environmental perturbants. A wide range of commensal, opportunistic and pathogenic bacterial groups including Staphylococcus spp. (both Staph. aureus and NAS), Streptococcus spp., E. coli, and lactic acid bacteria can adhere to and internalize epithelial cells of the bovine udder (Almeida et al., 1996; Dogan et al., 2006; Tamilselvam et al., 2006; Bouchard et al., 2015). Unfortunately, metagenomic studies have almost exclusively focused on 
microbiota of intramammary secretions and therefore overlooked the importance of tissue-associated microbiota in modulating udder homeostasis.

Systemic and local administrations of antimicrobials are undoubtedly the most important control measures capable of modifying microbial communities of the udder. In the context of bovine mastitis, antimicrobials are regularly used to treat $\mathrm{CM}$ during lactation (therapeutic) or to eliminate chronic IMI and prevent acquisition of new ones during the dry period (therapeutic and prophylactic; Hillerton et al., 2017). In the absence of effective alternative therapies, judicious use of antibiotics for treatment of CM is a well-justified practice with respect to animal welfare and public health. However, due to growing concerns regarding emergence of antimicrobial resistance in mastitis pathogens with zoonotic potential, prophylactic use of antibiotics in farm animals has become a subject of great concern for public health (Oliver et al., 2011; Tang et al., 2017). In addition, despite widespread and occasionally injudicious use of antibiotics, mastitis remains the most challenging disease of primiparous and multiparous cows worldwide (Pyörälä, 2008; De Vliegher et al., 2012); underscoring the need for thorough evaluation of the effect of common antimicrobial regimens on microbial communities inhabiting various compartments of the udder.

\section{Effect of Intramammary Administration of Antibiotics on Composition of Udder Microbiota}

Although numerous studies have investigated effectiveness of various antimicrobial products in eliminating/controlling major mastitis pathogens (Wilson et al., 1999; Barkema et al., 2006; Barlow, 2011; Schukken et al., 2011; Suojala et al., 2013; Oliveira and Ruegg, 2014; Royster and Wagner, 2015), there is only scant knowledge regarding effects of therapeutic and prophylactic usage of antimicrobials on overall composition of udder microbiota (Derakhshani et al., 2018). Longitudinal profiling of milk microbiota following natural (Ganda et al., 2016) or experimental (Ganda et al., 2017) IMI with pathogenic strains of E. coli suggested that extended intramammary administration of ceftiofur hydrochloride cannot substantially shorten the duration of mastitis or accelerate the elimination of pathogens. In both experiments, resolution of mastitis was accompanied by a quick return of milk microbiota to its healthy profile within $8 \mathrm{~d}$ after infection, irrespective of whether quarters were treated with ceftiofur. Similarly, extended exposure of healthy udder quarters to ceftiofur did not have a long-lasting effect on the composition of milk microbiota. Therefore, it was inferred that intramammary microbiota are not only resistant to invasion by gram-negative udder pathogens such as E. coli, but may also resist extended exposure to broad-spectrum, third-generation cephalosporins. Whether or not other classes of antimicrobials may have a long-lasting influence on the composition of udder microbiota is not clear. Also, to what extent routes of administration (systemic versus intramammary) can influence effects of various classes of antimicrobials on composition of udder microbiota remains largely unanswered. It was recently reported that both the class of the antimicrobial and its route of administration can affect prevalence of antimicrobial resistance in NAS species isolated from udder quarters (Nobrega et al., 2018). Whereas systemic use of penicillins, macrolides, and third-generation cephalosporins were strongly associated with prevalence of drug-specific resistances in NAS, intramammary administration of these antimicrobials was not associated with prevalence of antimicrobial resistance in NAS. In addition, despite the aforementioned 3 antimicrobial classes, neither systemic nor intramammary administration of any other antimicrobials investigated in the study of Nobrega et al. (2018) was associated with altered antimicrobial resistance in NAS. Therefore, we inferred that the response of udder microbiota to various classes of antimicrobials may also vary by route of administration, most likely due to varying intramammary concentrations of antimicrobials achieved after each route of administration. Another implication of the aforementioned study for udder microbiota would be the potential effect that systemic administration of antimicrobials for purposes other than treatment of mastitis and DCT may have on proportions and quantities of various commensals and pathogens in the udder ecosystem.

Intramammary administration of long-acting antibiotics at the end of lactation (i.e., dry cow therapy) is a key component of mastitis control programs. Whether used to treat every quarter of every cow (i.e., blanket) or every quarter of cows diagnosed with active/recurrent IMI (i.e., selective), DCT continues to be one of the main reasons for the use of antibiotics on dairy farms (Bradley and Green, 2004; Hillerton et al., 2017). Internal teat sealants have also been widely used in lieu of, or in combination with, antimicrobial DCT to prevent new IMI during the dry period (Berry and Hillerton, 2002; Bhutto et al., 2011). However, despite implementation of abovementioned intervention strategies, a high prevalence of periparturient mastitis remains a major problem worldwide (Pyörälä, 2008; De Vliegher et al., 2012). This underscores the need for further improvements of mastitis control programs, as well as a thorough evaluation of the effects of current DCT strategies in modulating microbiota of various udder compartments. In a recent study conducted by Bon- 
saglia et al. (2017), DCT using ceftiofur hydrochloride and an internal teat sealant did not decrease postpartal proportions of bacterial genera commonly regarded as major mastitis pathogens, including Escherichia, Klebsiella, Mycoplasma, Staphylococcus, and Streptococcus. However, it is worth noting that by failing to explore the microbiota of colostrum samples collected immediately after calving, this study remained inconclusive regarding persistence of various bacterial groups throughout the dry period. In partial agreement with the results of the referred study, colostrum microbiota of multiparous cows receiving blanket DCT using cloxacillin benzathine also had a high proportion of Staphylococcus, unclassified Enterobacteriaceae, and Pseudomonas (Lima et al., 2017). Obviously, DNA-based profiling of the udder microbiota is not a sound approach for drawing conclusions with respect to viability of various bacterial groups and persistency of their infections. Nonetheless, these findings emphasized the need for thorough evaluation of the effectiveness of current DCT strategies in eliminating various mastitis pathogens and modulating the composition of commensal udder microbiota. As mentioned earlier, another common yet critical shortcoming of above-mentioned studies was overlooking the effect of antimicrobials on microbiota profiles of udder compartments other than milk. Earlier studies indicated that microbial colonization of the TC with certain staphylococcal species could serve as a potential reservoir for development of new IMI (Haveri et al., 2008; Taponen et al., 2008; Quirk et al., 2012). Hence, simultaneous investigation of microbiota from the TC and intramammary secretions (i.e., colostrum and milk) would not only deepen our understanding regarding ecological relationships among various niches of the udder, but also enable us to evaluate effectiveness of various mastitis control programs (e.g., DCT) in a more comprehensive and precise manner.

\section{MICROBIOTA DYSBIOSIS: POTENTIAL IMPLICATIONS FOR UDDER HEALTH AND MASTITIS SUSCEPTIBILITY}

As mentioned, evidence is growing that the incidence of $\mathrm{CM}$ is associated with decreased diversity and altered composition (i.e., dysbiosis) of intramammary microbiota. However, it remains a matter of debate whether microbiota dysbiosis is the cause or consequence of infectious mastitis. Mastitis pathogens usually have a variety of virulence factors that enable them to overcome immune-mediated colonization of the udder (Barkema et al., 2006; Melchior et al., 2006). Consequently, following initial colonization, pathogens can rapidly overgrow the udder ecosystem and deplete its resident commensal microbiota (i.e., development of an alternate dysbiotic state with reduced species-richness and dominance of pathogenic and opportunistic microorganisms). However, pathogen dominance within an udder ecosystem usually does not persist and is resolved either spontaneously, due to activity of immune cells and clearance through regular milking, or with the aid of therapeutic interventions (e.g., systemic or intramammary antimicrobials). Regardless, resolution of pathogen-induced inflammatory responses of the udder is followed by subsequent microbial successions (Ganda et al., 2016; Ganda et al., 2017) that can either result in full recovery of depleted commensals or partial recovery of depleted species and development of a degraded state of udder microbiota. The extent of recovery of commensal bacteria relies partly on the spectrum of activity of antimicrobials used to treat mastitis, but also largely on virulence factors of invasive pathogens. Virulence characteristics such as biofilm formation and ability to internalize mammary epithelial cells enable certain mastitis pathogens to occupy distinct niches of the udder for extended intervals (Melchior et al., 2006), and by doing so, suppress regrowth of commensal bacteria. Depletion of commensal bacteria may have deleterious effects on udder homeostasis and mastitis resistance. Commensals can resist colonization of exogenous pathogens and inhibit overgrowth of indigenous opportunists via several mechanisms, including metabolic competition over limiting nutrient resources, production of inhibitory peptides (e.g., bacteriocins) altering ecosystem conditions to disfavor pathogen growth (e.g., lowering $\mathrm{pH}$ ), competition over attachment sites on surface of epithelial cells, and regulation of pro- and anti-inflammatory responses of the host (Konopka, 2009; Hooper et al., 2012; Kamada et al., 2013). Hence, partial recovery of commensal bacteria following IMI and antimicrobial therapy may facilitate both development of new IMI and recurrence of persistent infections (Figure 4).

\section{CONCLUSIONS}

Growing interest in development of novel therapeutics for treatment of bovine mastitis dictates the need to gain a better understanding of various factors capable of influencing mammary homeostasis. Commensal microbiota that inhabit various niches of the udder, including teat apex, TC, and intramammary ecosystem, can modulate a cow's susceptibility to IMI by mastitis pathogens via direct microbe-microbe cross-talk, indirect stimulation of immunity, or both. Although still in its infancy, current understanding of the microbial ecosystem of the udder suggests that optimal diversity of intramammary microbiota, composed of a healthy balance between commensal and opportunistic bacterial 
Stable Eubiotic Udder Microbiota

Healthy status with high diversity and resilient

to colonization by exogenous microbes

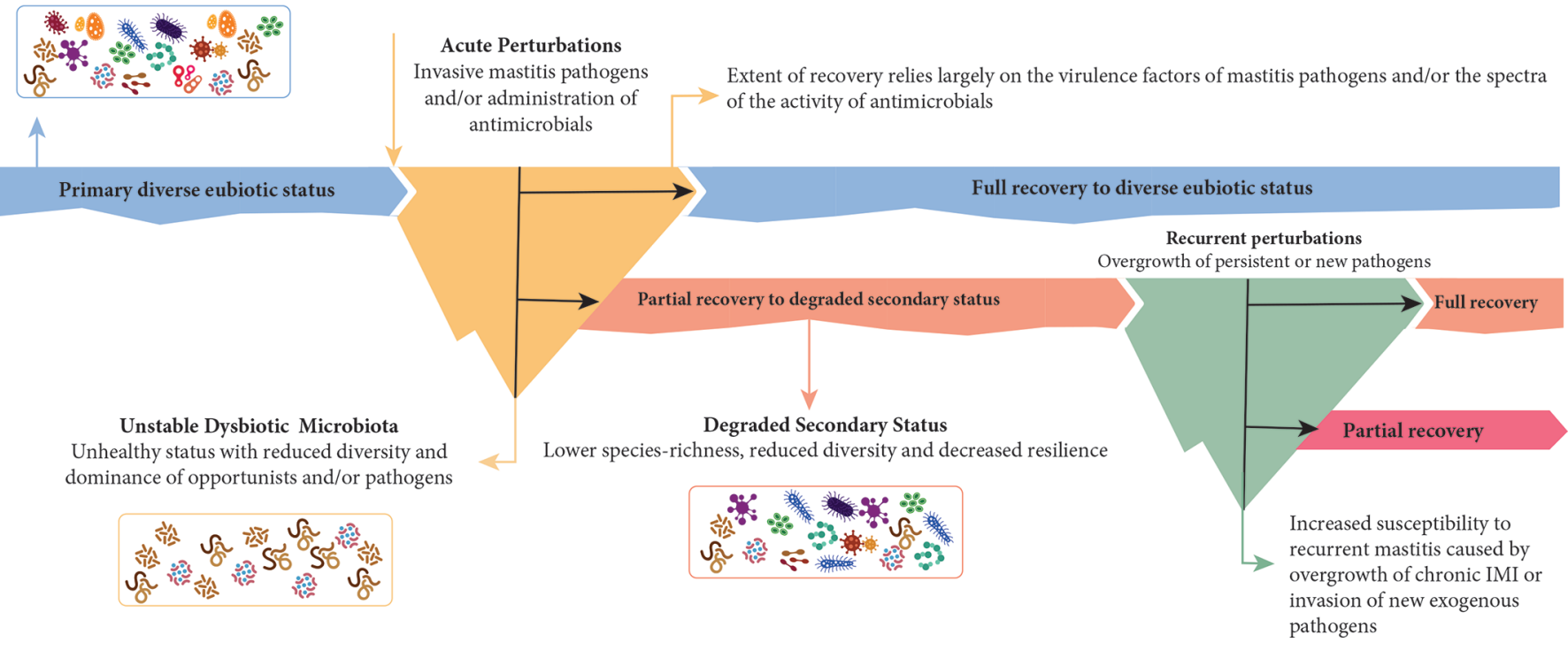

Figure 4. Potential role of microbiota dysbiosis in modulating mastitis susceptibility. Mastitis pathogens along with prophylactic and therapeutic use of antimicrobials are major forces affecting development of microbiota dysbiosis within the udder ecosystem. The diagram depicts potential contributions of healthy and eubiotic status of the udder microbiota in maintaining udder homeostasis and modulating mastitis resistance. Color version available online.

groups, is essential for maintaining an equilibrium between pro- and anti-inflammatory responses, and thus maintaining mammary homeostasis. The physiological status of the cow, anatomical characteristics of the udder, genetic traits associated with immune responsiveness, and environmental factors can alter composition of udder microbiota. However, whether various profiles of mammary microbiota can confer resistance to IMI by mastitis pathogens remains poorly understood. Great effort is needed to identify potential mechanisms by which commensal microbiota of various compartments of the udder interact with each other, with mastitis pathogens, and the immune system.

\section{ACKNOWLEDGMENTS}

The present research is supported by grants from Natural Science and Engineering Research Council of Canada-Discovery Program; Growing Forward 2-Agricultural Rural Development Initiative Program of the Province of Manitoba, Canada; and Dairy Farmers of Manitoba, Canada.

\section{REFERENCES}

Aakko, J., H. Kumar, S. Rautava, A. Wise, C. Autran, L. Bode, E. Isolauri, and S. Salminen. 2017. Human milk oligosaccharide categories define the microbiota composition in human colostrum. Benef. Microbes 8:563-567.
Addis, M. F., A. Tanca, S. Uzzau, G. Oikonomou, R. C. Bicalho, and P. Moroni. 2016. The bovine milk microbiota: insights and perspectives from -omics studies. Mol. Biosyst. 12:2359-2372.

Almeida, R. A., K. R. Matthews, E. Cifrian, A. J. Guidry, and S. P. Oliver. 1996. Staphylococcus aureus invasion of bovine mammary epithelial cells. J. Dairy Sci. 79:1021-1026.

Arroyo, R., V. Martín, A. Maldonado, E. Jiménez, L. Fernández, and J. M. Rodríguez. 2010. Treatment of infectious mastitis during lactation: Antibiotics versus oral administration of Lactobacilli isolated from breast milk. Clin. Infect. Dis. 50:1551-1558.

Banchereau, J., and R. M. Steinman. 1998. Dendritic cells and the control of immunity. Nature 392:245-252.

Bannerman, D. D., M. J. Paape, W. R. Hare, and E. J. Sohn. 2003 Increased levels of LPS-binding protein in bovine blood and milk following bacterial lipopolysaccharide challenge. J. Dairy Sci. 86:3128-3137.

Barkema, H. W., Y. H. Schukken, T. J. G. M. Lam, M. L. Beiboer, G. Benedictus, and A. Brand. 1999. Management practices associated with the incidence rate of clinical mastitis. J. Dairy Sci. 82:1643-1654.

Barkema, H. W., Y. H. Schukken, T. J. G. M. Lam, M. L. Beiboer, H. Wilmink, G. Benedictus, and A. Brand. 1998. Incidence of clinical mastitis in dairy herds grouped in three categories by bulk milk somatic cell counts. J. Dairy Sci. 81:411-419.

Barkema, H. W., Y. H. Schukken, and R. N. Zadoks. 2006. Invited review: The role of cow, pathogen, and treatment regimen in the therapeutic success of bovine Staphylococcus aureus mastitis. J. Dairy Sci. 89:1877-1895.

Barlow, J. 2011. Mastitis therapy and antimicrobial susceptibility: a multispecies review with a focus on antibiotic treatment of mastitis in dairy cattle. J. Mammary Gland Biol. Neoplasia 16:383-407.

Behl, J. D., N. Verma, N. Tyagi, P. Mishra, R. Behl, and B. Joshi 2012. The major histocompatibility complex in bovines: A review. ISRN Vet. Sci. 2012:872710.

Berry, E. A., and J. E. Hillerton. 2002. The effect of an intramammary teat seal on new intramammary infections. J. Dairy Sci. $85: 2512-2520$ 
Bhatt, V. D., V. B. Ahir, P. G. Koringa, S. J. Jakhesara, D. N. Rank, D. S. Nauriyal, A. P. Kunjadia, and C. J. Joshi. 2012. Milk microbiome signatures of subclinical mastitis-affected cattle analysed by shotgun sequencing. J. Appl. Microbiol. 112:639-650.

Bhutto, A. L., R. D. Murray, and Z. Woldehiwet. 2010. Udder shape and teat-end lesions as potential risk factors for high somatic cell counts and intra-mammary infections in dairy cows. Vet. J. 183:63-67.

Bhutto, A. L., R. D. Murray, and Z. Woldehiwet. 2011. The effect of dry cow therapy and internal teat-sealant on intra-mammary infections during subsequent lactation. Res. Vet. Sci. 90:316-320.

Biddle, M. K., L. K. Fox, M. A. Evans, and C. C. Gay. 2005. Pulsedfield gel electrophoresis patterns of Mycoplasma isolates from various body sites in dairy cattle with Mycoplasma mastitis. J. Am. Vet. Med. Assoc. 227:455-459.

Bolnick, D. I., L. K. Snowberg, J. G. Caporaso, C. Lauber, R. Knight, and W. E. Stutz. 2014. Major Histocompatibility Complex class IIb polymorphism influences gut microbiota composition and diversity. Mol. Ecol. 23:4831-4845.

Bonsaglia, E. C., M. S. Gomes, I. F. Canisso, Z. Zhou, S. F. Lima, V. L. Rall, G. Oikonomou, R. C. Bicalho, and F. S. Lima. 2017. Milk microbiome and bacterial load following dry cow therapy without antibiotics in dairy cows with healthy mammary gland. Sci. Rep. $7: 8067$.

Bouchard, D. S., B. Seridan, T. Saraoui, L. Rault, P. Germon, C. Gonzalez-Moreno, F. M. Nader-Macias, D. Baud, P. François, and V. Chuat. 2015. Lactic acid bacteria isolated from bovine mammary microbiota: potential allies against bovine mastitis. PLoS One 10:e0144831.

Bradley, A. J. 2002. Bovine mastitis: An evolving disease. Vet. J. 164:116-128.

Bradley, A. J., and M. J. Green. 2004. The importance of the nonlactating period in the epidemiology of intramammary infection and strategies for prevention. Vet. Clin. North Am. Food Anim. Pract. 20:547-568.

Braem, G., S. De Vliegher, B. Verbist, M. Heyndrickx, F. Leroy, and L. De Vuyst. 2012. Culture-independent exploration of the teat apex microbiota of dairy cows reveals a wide bacterial species diversity. Vet. Microbiol. 157:383-390.

Braem, G., B. Stijlemans, W. Haken, S. Vliegher, L. Vuyst, and F. Leroy. 2014. Antibacterial activities of coagulase-negative staphylococci from bovine teat apex skin and their inhibitory effect on mastitis-related pathogens. J. Appl. Microbiol. 116:1084-1093.

Breen, J. E., M. J. Green, and A. J. Bradley. 2009. Quarter and cow risk factors associated with the occurrence of clinical mastitis in dairy cows in the United Kingdom. J. Dairy Sci. 92:2551-2561.

Cabrera-Rubio, R., M. C. Collado, K. Laitinen, S. Salminen, E. Isolauri, and A. Mira. 2012. The human milk microbiome changes over lactation and is shaped by maternal weight and mode of delivery. Am. J. Clin. Nutr. 96:544-551.

Carabotti, M., A. Scirocco, M. A. Maselli, and C. Severi. 2015. The gut-brain axis: Interactions between enteric microbiota, central and enteric nervous systems. Ann. Gastroenterol. 28:203-209.

Carson, D. A., H. W. Barkema, S. Naushad, and J. De Buck. 2017. Bacteriocins of non-aureus staphylococci isolated from bovine milk. Appl. Environ. Microbiol. 83:e01015-e01017.

Chrystal, M. A., A. J. Seykora, L. B. Hansen, A. E. Freeman, D. H. Kelley, and M. H. Healey. 2001. Heritability of teat-end shape and the relationship of teat-end shape with somatic cell score for an experimental herd of cows. J. Dairy Sci. 84:2549-2554.

Condas, L. A., J. De Buck, D. B. Nobrega, D. A. Carson, S. Naushad, S. De Vliegher, R. N. Zadoks, J. R. Middleton, S. Dufour, and J. P. Kastelic. 2017a. Prevalence of non-aureus staphylococci species causing intramammary infections in Canadian dairy herds. J. Dairy Sci. 100:5592-5612.

Condas, L. A. Z., J. De Buck, D. B. Nobrega, D. A. Carson, J.-P. Roy, G. P. Keefe, T. J. DeVries, J. R. Middleton, S. Dufour, and H. W. Barkema. 2017b. Distribution of non-aureus staphylococci species in udder quarters with low and high somatic cell count, and clinical mastitis. J. Dairy Sci. 100:5613-5627.
Costello, E. K., C. L. Lauber, M. Hamady, N. Fierer, J. I. Gordon, and R. Knight. 2009. Bacterial community variation in human body habitats across space and time. Science 326:1694-1697.

Costello, E. K., K. Stagaman, L. Dethlefsen, B. J. Bohannan, and D. A. Relman. 2012. The application of ecological theory toward an understanding of the human microbiome. Science 336:1255-1262.

Cryan, J. F., and S. O'Mahony. 2011. The microbiome-gut-brain axis: From bowel to behavior. Neurogastroenterol. Motil. 23:187-192.

De Koster, J. D., and G. Opsomer. 2013. Insulin resistance in dairy cows. Vet. Clin. North Am. Food Anim. Pract. 29:299-322.

De Palma, G. A. Capilla, I. Nadal, E. Nova, T. Pozo, V. Varea, I. Polanco, G. Castillejo, A. López, and J. A. Garrote. 2010. Interplay between human leukocyte antigen genes and the microbial colonization process of the newborn intestine. Curr. Issues Mol. Biol. 12:1-10.

De Visscher, A., K. Supré, F. Haesebrouck, R. N. Zadoks, V. Piessens, E. Van Coillie, S. Piepers, and S. De Vliegher. 2014. Further evidence for the existence of environmental and host-associated species of coagulase-negative staphylococci in dairy cattle. Vet. Microbiol. 172:466-474.

De Vliegher, S., L. K. Fox, S. Piepers, S. McDougall, and H. W. Barkema. 2012. Invited review: Mastitis in dairy heifers: Nature of the disease, potential impact, prevention, and control. J. Dairy Sci. 95:1025-1040.

De Vliegher, S., G. Opsomer, A. Vanrolleghem, L. A. Devriese, O. C. Sampimon, J. Sol, H. W. Barkema, F. Haesebrouck, and A. de Kruif. 2004. In vitro growth inhibition of major mastitis pathogens by Staphylococcus chromogenes originating from teat apices of dairy heifers. Vet. Microbiol. 101:215-221.

Derakhshani, H., J. C. Plaizier, J. De Buck, H. W. Barkema, and E. Khafipour. 2018. Composition of teat canal and intramammary microbiota of dairy cows subjected to antimicrobial dry cow therapy and internal teat sealant. J. Dairy Sci. 101:10191-10205. https: //doi.org/10.3168/jds.2018-14858.

Derakhshani, H., J. C. Plaizier, and E. Khafipour. 2017a. Bacterial ecosystem of the bovine mammary gland: potential role of foundation taxa in shaping mammary gland microbiota and modulating udder homeostasis. J. Dairy Sci. 100(Suppl. 2.):232. (Abstr.)

Derakhshani, H., J. C. Plaizier, and E. Khafipour. 2017b. The commensal microbiota of bovine mammary gland: cross-talk with host genotype and its potential role in modulating mastitis susceptibility. J. Dairy Sci. 100(Suppl. 2):i. (Abstr.)

Derakhshani, H., H. M. Tun, F. C. Cardoso, J. C. Plaizier, E. Khafipour, and J. J. Loor. 2017c. Linking peripartal dynamics of ruminal microbiota to dietary changes and production parameters. Front. Microbiol. 7:2143

Detilleux, J. C. 2009. Genetic factors affecting susceptibility to udder pathogens. Vet. Microbiol. 134:157-164.

Detilleux, J. C., M. E. Kehrli, J. R. Stabel, A. E. Freeman, and D. H. Kelley. 1995. Study of immunological dysfunction in periparturient Holstein cattle selected for high and average milk production. Vet. Immunol. Immunopathol. 44:251-267.

Dietz, A. B., N. D. Cohen, L. Timms, and M. E. Kehrli. 1997. Bovine Lymphocyte Antigen Class II alleles as risk factors for high somatic cell counts in milk of lactating dairy cows. J. Dairy Sci. 80:406-412.

Dingwell, R. T., K. E. Leslie, Y. H. Schukken, J. M. Sargeant, L. L. Timms, T. F. Duffield, G. P. Keefe, D. F. Kelton, K. D. Lissemore, and J. Conklin. 2004. Association of cow and quarter-level factors at drying-off with new intramammary infections during the dry period. Prev. Vet. Med. 63:75-89.

Dogan, B., S. Klaessig, M. Rishniw, R. A. Almeida, S. P. Oliver, K. Simpson, and Y. H. Schukken. 2006. Adherent and invasive Escherichia coli are associated with persistent bovine mastitis. Vet. Microbiol. 116:270-282.

Doyle, C. J., D. Gleeson, P. W. O'Toole, and P. D. Cotter. 2016. Impacts of seasonal housing and teat preparation on raw milk microbiota: A high-throughput sequencing study. Appl. Environ. Microbiol. 83:e02694-e02716.

Duffield, T. 2000. Subclinical ketosis in lactating dairy cattle. Vet. Clin. North Am. Food Anim. Pract. 16:231-253. 
Esposito, G., P. C. Irons, E. C. Webb, and A. Chapwanya. 2014. Interactions between negative energy balance, metabolic diseases, uterine health and immune response in transition dairy cows. Anim. Reprod. Sci. 144:60-71.

Falentin, H., L. Rault, A. Nicolas, D. S. Bouchard, J. Lassalas, P. Lamberton, J.-M. Aubry, P. G. Marnet, Y. Le Loir, and S. Even. 2016. Bovine teat microbiome analysis revealed reduced alpha diversity and significant changes in taxonomic profiles in quarters with a history of mastitis. Front. Microbiol. 7:480.

Fehr, K. B., H. Derakhshani, S. Sepehri, J. C. Plaizier, and E. Khafipour. 2017. Effects of dairy environment on milk microbiota and mammary inflammation. J. Dairy Sci. 100(Suppl. 2):142. (Abstr.)

Fernández, L., S. Langa, V. Martín, A. Maldonado, E. Jiménez, R. Martín, and J. M. Rodríguez. 2013. The human milk microbiota: Origin and potential roles in health and disease. Pharmacol. Res. 69:1-10.

Fox, L. K., J. H. Kirk, and A. Britten. 2005. Mycoplasma mastitis: A review of transmission and control. Zoonoses Public Health $52: 153-160$.

Franzosa, E. A., T. Hsu, A. Sirota-Madi, A. Shafquat, G. Abu-Ali, X. C. Morgan, and C. Huttenhower. 2015. Sequencing and beyond: Integrating molecular 'omics for microbial community profiling. Nat. Rev. Microbiol. 13:360.

Fyhrquist, N., L. Ruokolainen, A. Suomalainen, S. Lehtimäki, V. Veckman, J. Vendelin, P. Karisola, M. Lehto, T. Savinko, and H. Jarva. 2014. Acinetobacter species in the skin microbiota protect against allergic sensitization and inflammation. J. Allergy Clin. Immunol. 134:1301-1309. e1311.

Ganda, E. K., R. S. Bisinotto, S. F. Lima, K. Kronauer, D. H. Decter, G. Oikonomou, Y. H. Schukken, and R. C. Bicalho. 2016. Longitudinal metagenomic profiling of bovine milk to assess the impact of intramammary treatment using a third-generation cephalosporin. Sci. Rep. 6:37565.

Ganda, E. K., N. Gaeta, A. Sipka, B. Pomeroy, G. Oikonomou, Y. H. Schukken, and R. C. Bicalho. 2017. Normal milk microbiome is reestablished following experimental infection with Escherichia coli independent of intramammary antibiotic treatment with a thirdgeneration cephalosporin in bovines. Microbiome 5:74.

Gill, H. S., F. Doull, K. Rutherfurd, and M. Cross. 2000. Immunoregulatory peptides in bovine milk. Br. J. Nutr. 84:S111-S117.

Gill, J. J., P. M. Sabour, J. Gong, H. Yu, K. E. Leslie, and M. W. Griffiths. 2006. Characterization of bacterial populations recovered from the teat canals of lactating dairy and beef cattle by $16 \mathrm{~S}$ rRNA gene sequence analysis. FEMS Microbiol. Ecol. 56:471-481.

Godden, S., R. Bey, K. Lorch, R. Farnsworth, and P. Rapnicki. 2008. Ability of organic and inorganic bedding materials to promote growth of environmental bacteria. J. Dairy Sci. 91:151-159.

Goff, J. P. 2006. Major advances in our understanding of nutritional influences on bovine health. J. Dairy Sci. 89:1292-1301.

Goodman, A. L., G. Kallstrom, J. J. Faith, A. Reyes, A. Moore, G. Dantas, and J. I. Gordon. 2011. Extensive personal human gut microbiota culture collections characterized and manipulated in gnotobiotic mice. Proc. Natl. Acad. Sci. USA 108:6252-6257.

Gopal, P. K., and H. Gill. 2000. Oligosaccharides and glycoconjugates in bovine milk and colostrum. Br. J. Nutr. 84:S69-S74.

Green, M. J., A. J. Bradley, G. F. Medley, and W. J. Browne. 2007. Cow, farm, and management factors during the dry period that determine the rate of clinical mastitis after calving. J. Dairy Sci. 90:3764-3776

Green, M. J., L. E. Green, G. F. Medley, Y. H. Schukken, and A. J. Bradley. 2002. Influence of dry period bacterial intramammary infection on clinical mastitis in dairy cows. J. Dairy Sci. 85:25892599.

Grice, E. A., E. S. Snitkin, L. J. Yockey, D. M. Bermudez, K. W. Liechty, J. A. Segre, J. Mullikin, R. Blakesley, A. Young, and G. Chu. 2010. Longitudinal shift in diabetic wound microbiota correlates with prolonged skin defense response. Proc. Natl. Acad. Sci. USA 107:14799-14804.

Grummer, R. R., D. G. Mashek, and A. Hayirli. 2004. Dry matter intake and energy balance in the transition period. Vet. Clin. North Am. Food Anim. Pract. 20:447-470.
Hameed, K. G. A., G. Sender, and M. Mayntz. 2006. Major histocompatibility complex polymorphism and mastitis resistance-a review. Anim. Sci. Pap. Rep. 24:11-25.

Haveri, M., M. Hovinen, A. Roslöf, and S. Pyörälä. 2008. Molecular types and genetic profiles of Staphylococcus aureus strains isolated from bovine intramammary infections and extramammary sites. J. Clin. Microbiol. 46:3728-3735.

Heringstad, B., G. Klemetsdal, and J. Ruane. 2000. Selection for mastitis resistance in dairy cattle: A review with focus on the situation in the Nordic countries. Livest. Prod. Sci. 64:95-106.

Hillerton, E., M. Bryan, A. Biggs, E. Berry, and P. Edmondson. 2017. Time to standardise dry cow therapy terminology. Vet. Rec. 180:301-302.

Hogan, J. S., K. L. Smith, D. A. Todhunter, and P. S. Schoenberger. 1988. Rate of environmental mastitis in quarters infected with Corynebacterium bovis and Staphylococcus species. J. Dairy Sci. $71: 2520-2525$.

Hooper, L. V., D. R. Littman, and A. J. Macpherson. 2012. Interactions between the microbiota and the immune system. Science $336: 1268-1273$

Ingvartsen, K. L., and K. Moyes. 2013. Nutrition, immune function and health of dairy cattle. Animal 7:112-122.

Isaacs, C. E. 2005. Human milk inactivates pathogens individually, additively, and synergistically. J. Nutr. 135:1286-1288.

Jiménez, E., L. Fernández, A. Maldonado, R. Martín, M. Olivares, J. Xaus, and J. M. Rodríguez. 2008. Oral administration of lactobacillus strains isolated from breast milk as an alternative for the treatment of infectious mastitis during lactation. Appl. Environ. Microbiol. 74:4650-4655.

Jones, G. M., and T. L. Bailey. 2009. Understanding the basics of mastitis. Virginia Cooperative Extension. Publication 404-233.

Kamada, N., G. Y. Chen, N. Inohara, and G. Núñez. 2013. Control of pathogens and pathobionts by the gut microbiota. Nat. Immunol. 14:685-690.

Kehrli, M. E., and J. A. Harp. 2001. Immunity in the mammary gland. Vet. Clin. North Am. Food Anim. Pract. 17:495-516.

Kelm, S. C., J. C. Dettilleux, A. E. Freeman, M. E. Kehrli, A. B. Dietz, L. K. Fox, J. E. Butler, I. Kasckovics, and D. H. Kelley. 1997. Genetic association between parameters of innate immunity and measures of mastitis in periparturient Holstein cattle. J. Dairy Sci 80:1767-1775

Khafipour, E., H. Derakhshani, K. B. Fehr, H. Khalouei, Z. Zhang, and J. C. Plaizier. 2017. 757 Associations between gut, mammary and vaginal microbiomes in dairy cows: Role in health and disease. J. Anim. Sci. 95:366.

Khafipour, E., D. O. Krause, and J. C. Plaizier. 2009a. A grain-based subacute ruminal acidosis challenge causes translocation of lipopolysaccharide and triggers inflammation. J. Dairy Sci. 92:10601070.

Khafipour, E., S. Li, J. C. Plaizier, and D. O. Krause. 2009b. Rumen microbiome composition determined using two nutritional models of subacute ruminal acidosis. Appl. Environ. Microbiol. 75:7115-7124

Konopka, A. 2009. What is microbial community ecology? ISME J. $3: 1223-1230$.

Korhonen, H., P. Marnila, and H. S. Gill. 2000. Milk immunoglobulins and complement factors. Br. J. Nutr. 84:S75-S80.

Krömker, V., and J. Friedrich. 2009. Teat canal closure in non-lactating heifers and its association with udder health in the consecutive lactation. Vet. Microbiol. 134:100-105.

Kubinak, J. L., W. Z. Stephens, R. Soto, C. Petersen, T. Chiaro, L. Gogokhia, R. Bell, N. J. Ajami, J. F. Petrosino, and L. Morrison. 2015. MHC variation sculpts individualized microbial communities that control susceptibility to enteric infection. Nat. Commun. $6: 8642$.

Kuehn, J. S., P. J. Gorden, D. Munro, R. Rong, Q. Dong, P. J. Plummer, C. Wang, and G. J. Phillips. 2013. Bacterial community profiling of milk samples as a means to understand culture-negative bovine clinical mastitis. PLoS One 8:e61959.

Lagier, J. C., F. Armougom, M. Million, P. Hugon, I. Pagnier, C. Robert, F. Bittar, G. Fournous, G. Gimenez, and M. Maraninchi. 
2012. Microbial culturomics: Paradigm shift in the human gut microbiome study. Clin. Microbiol. Infect. 18:1185-1193.

Lau, J. T., F. J. Whelan, I. Herath, C. H. Lee, S. M. Collins, P. Bercik, and M. G. Surette. 2016. Capturing the diversity of the human gut microbiota through culture-enriched molecular profiling. Genome Med. 8:72.

Leach, K. A., S. C. Archer, J. E. Breen, M. J. Green, I. C. Ohnstad, S. Tuer, and A. J. Bradley. 2015. Recycling manure as cow bedding: Potential benefits and risks for UK dairy farms. Vet. J. 206:123-130.

Leigh, J. A. 1999. Streptococcus uberis: A permanent barrier to the control of bovine mastitis? Vet. J. 157:225-238.

Leslie, K. E., T. F. Duffield, Y. H. Schukken, and S. J. LeBlanc. 2000. The influence of negative energy balance on udder health. Pages 25-33 in National Mastitis Council Regional Meeting Proceedings. Omnipress, Madison, WI.

Lima, F. S., G. Oikonomou, S. F. Lima, M. L. Bicalho, E. K. Ganda, J. C. de Oliveira Filho, G. Lorenzo, P. Trojacanec, and R. C. Bicalho. 2015. Prepartum and postpartum rumen fluid microbiomes: characterization and correlation with production traits in dairy cows. Appl. Environ. Microbiol. 81:1327-1337.

Lima, S. F., A. G. Teixeira, F. S. Lima, E. K. Ganda, C. H. Higgins, G. Oikonomou, and R. C. Bicalho. 2017. The bovine colostrum microbiome and its association with clinical mastitis. J. Dairy Sci. 100:3031-3042

Lozupone, C. A., J. I. Stombaugh, J. I. Gordon, J. K. Jansson, and R. Knight. 2012. Diversity, stability and resilience of the human gut microbiota. Nature 489:220-230.

Macpherson, A. J., and T. Uhr. 2004. Induction of protective IgA by intestinal dendritic cells carrying commensal bacteria. Science 303:1662-1665.

Mallard, B., J. Dekkers, M. Ireland, K. Leslie, S. Sharif, C. L. Vankampen, L. Wagter, and B. Wilkie. 1998. Alteration in immune responsiveness during the peripartum period and its ramification on dairy cow and calf health. J. Dairy Sci. 81:585-595.

Matthews, K. R., R. J. Harmon, and B. E. Langlois. 1992. Prevalence of Staphylococcus species during the periparturient period in primiparous and multiparous cows. J. Dairy Sci. 75:1835-1839.

Matthews, K. R., R. J. Harmon, and B. A. Smith. 1990. Protective effect of Staphylococcus chromogenes infection against Staphylococcus aureus infection in the lactating bovine mammary gland. J. Dairy Sci. 73:3457-3462.

McDougall, S., K. I. Parker, C. Heuer, and C. W. R. Compton. 2009 A review of prevention and control of heifer mastitis via non-antibiotic strategies. Vet. Microbiol. 134:177-185.

Mehrzad, J., L. Duchateau, S. Pyörälä, and C. Burvenich. 2002. Blood and milk neutrophil chemiluminescence and viability in primiparous and pluriparous dairy cows during late pregnancy, around parturition and early lactation. J. Dairy Sci. 85:3268-3276.

Mein, G., D. Reinemann, N. Schuring, and I. Ohnstad. 2004. R-MM-1: Milking machines and mastitis risk-A storm in a teatcup. Proceedings of the National Mastitis Council Annual Meeting. pp 176-188.

Melchior, M. B., H. Vaarkamp, and J. Fink-Gremmels. 2006. Biofilms: A role in recurrent mastitis infections? Vet. J. 171:398-407.

Middleton, J. R., A. Saeman, L. K. Fox, J. Lombard, J. S. Hogan, and K. L. Smith. 2014. The National Mastitis Council: A global organization for mastitis control and milk quality, 50 years and beyond. J. Mammary Gland Biol. Neoplasia 19:241-251.

Monfardini, E., M. J. Paape, Y. Wang, A. V. Capuco, M. Husheem, L. Wood, and C. Burvenich. 2002. Evaluation of L-selectin expression and assessment of protein tyrosine phosphorylation in bovine polymorphonuclear neutrophil leukocytes around parturition. Vet. Res. 33:271-281.

Morrow, A. L., and J. M. Rangel. 2004. Human milk protection against infectious diarrhea: Implications for prevention and clinical care. Semin. Pediatr. Infect. Dis. Proc. 15:221-228.

Neijenhuis, F., H. W. Barkema, H. Hogeveen, and J. P. T. M. Noordhuizen. 2000. Classification and longitudinal examination of callused teat ends in dairy cows. J. Dairy Sci. 83:2795-2804.
Neijenhuis, F., H. W. Barkema, H. Hogeveen, and J. P. T. M. Noordhuizen. 2001a. Relationship between teat-end callosity and occurrence of clinical mastitis. J. Dairy Sci. 84:2664-2672.

Neijenhuis, F., G. A. Mein, J. S. Britt, D. J. Reinemann, J. E. Hillerton, R. Farnsworth, J. R. Baines, T. Hemling, I. Ohnstad, and N. Cook. 2001b. Evaluation of bovine teat condition in commercial dairy herds: 4 . Relationship between teat-end callosity or hyperkeratosis and mastitis. Pages 362-366 in Proceedings of the 2nd International Symposium on Mastitis and Milk Quality.

Nemergut, D. R., S. K. Schmidt, T. Fukami, S. P. O'Neill, T. M. Bilinski, L. F. Stanish, J. E. Knelman, J. L. Darcy, R. C. Lynch, and P. Wickey. 2013. Patterns and processes of microbial community assembly. Microbiol. Mol. Biol. Rev. 77:342-356.

Newburg, D. S. 2005. Innate immunity and human milk. J. Nutr. 135:1308-1312.

Nobrega, D. B., J. De Buck, and H. W. D. Barkema. 2018. Antimicrobial resistance in non-aureus staphylococci isolated from milk is associated with systemic but not intramammary administration of antimicrobials in dairy cattle. J. Dairy Sci. 101:7425-7436.

Oikonomou, G., M. L. Bicalho, E. Meira, R. E. Rossi, C. Foditsch, V. S. Machado, A. G. V. Teixeira, C. Santisteban, Y. H. Schukken, and R. C. Bicalho. 2014. Microbiota of cow's milk; distinguishing healthy, sub-clinically and clinically diseased quarters. PLoS One 9:e85904.

Oikonomou, G., V. S. Machado, C. Santisteban, Y. H. Schukken, and R. C. Bicalho. 2012. Microbial diversity of bovine mastitic milk as described by pyrosequencing of metagenomic $16 \mathrm{~s}$ rDNA. PLoS One 7:e47671.

Oliveira, L., and P. L. Ruegg. 2014. Treatments of clinical mastitis occurring in cows on 51 large dairy herds in Wisconsin. J. Dairy Sci. 97:5426-5436.

Oliver, S. P., S. E. Murinda, and B. M. Jayarao. 2011. Impact of antibiotic use in adult dairy cows on antimicrobial resistance of veterinary and human pathogens: A comprehensive review. Foodborne Pathog. Dis. 8:337-355.

Oliver, S. P., and L. M. Sordillo. 1988. Udder health in the periparturient period. J. Dairy Sci. 71:2584-2606.

Oviedo-Boyso, J., J. J. Valdez-Alarcón, M. Cajero-Juárez, A. OchoaZarzosa, J. E. López-Meza, A. Bravo-Patiño, and V. M. Baizabal-Aguirre. 2007. Innate immune response of bovine mammary gland to pathogenic bacteria responsible for mastitis. J. Infect. 54:399-409.

Paduch, J. H., E. Mohr, and V. Krömker. 2012. The association between teat end hyperkeratosis and teat canal microbial load in lactating dairy cattle. Vet. Microbiol. 158:353-359.

Paganelli, R., A. Di Iorio, A. Cherubini, F. Lauretani, C. Mussi, S. Volpato, M. Abate, G. Abate, and L. Ferrucci. 2006. Frailty of older age: The role of the endocrine-immune interaction. Curr. Pharm. Des. 12:3147-3159.

Paulrud, C. O. 2005. Basic concepts of the bovine teat canal. Vet. Res. Commun. 29:215-245.

Persson, K., I. Larsson, and C. H. Sandgren. 1993. Effects of certain inflammatory mediators on bovine neutrophil migration in vivo and in vitro. Vet. Immunol. Immunopathol. 37:99-112.

Pighetti, G. M., and A. Elliott. 2011. Gene polymorphisms: The keys for marker assisted selection and unraveling core regulatory pathways for mastitis resistance. J. Mammary Gland Biol. Neoplasia $16: 421-432$.

Plaizier, J. C., E. Khafipour, S. Li, G. N. Gozho, and D. O. Krause. 2012. Subacute ruminal acidosis (SARA), endotoxins and health consequences. Anim. Feed Sci. Technol. 172:9-21.

Plaizier, J. C., D. O. Krause, G. N. Gozho, and B. W. McBride. 2008. Subacute ruminal acidosis in dairy cows: The physiological causes, incidence and consequences. Vet. J. 176:21-31.

Pyörälä, S. 2008. Mastitis in post-partum dairy cows. Reprod. Domest. Anim. 43:252-259.

Pyörälä, S., and S. Taponen. 2009. Coagulase-negative staphylococciEmerging mastitis pathogens. Vet. Microbiol. 134:3-8. 
Quigley, L., O. O'Sullivan, C. Stanton, T. P. Beresford, R. P. Ross, G. F. Fitzgerald, and P. D. Cotter. 2013. The complex microbiota of raw milk. FEMS Microbiol. Rev. 37:664-698.

Quirk, T., L. K. Fox, D. D. Hancock, J. Capper, J. Wenz, and J. Park. 2012. Intramammary infections and teat canal colonization with coagulase-negative staphylococci after postmilking teat disinfection: Species-specific responses. J. Dairy Sci. 95:1906-1912.

Rainard, P. 2017. Mammary microbiota of dairy ruminants: Fact or fiction? Vet. Res. (Faisalabad) 48:25.

Rainard, P., and C. Riollet. 2006. Innate immunity of the bovine mammary gland. Vet. Res. 37:369-400.

Rescigno, M., M. Urbano, B. Valzasina, M. Francolini, G. Rotta, R. Bonasio, F. Granucci, J.-P. Kraehenbuhl, and P. Ricciardi-Castagnoli. 2001. Dendritic cells express tight junction proteins and penetrate gut epithelial monolayers to sample bacteria. Nat. Immunol. 2:361.

Rice, D. A., and S. Kennedy. 1988. Assessment of vitamin E, selenium and polyunsaturated fatty acid interactions in the aetiology of disease in the bovine. Proc. Nutr. Soc. 47:177-184.

Rodríguez, J. M. 2014. The origin of human milk bacteria: Is there a bacterial entero-mammary pathway during late pregnancy and lactation? Adv. Nutr. 5:779-784.

Rowbotham, R. F., and P. L. Ruegg. 2015. Association of bedding types with management practices and indicators of milk quality on larger Wisconsin dairy farms. J. Dairy Sci. 98:7865-7885.

Royster, E., and S. Wagner. 2015. Treatment of mastitis in cattle. Vet. Clin. North Am. Food Anim. Pract. 31:17-46.

Rupp, R., and D. Boichard. 2003. Genetics of resistance to mastitis in dairy cattle. Vet. Res. 34:671-688.

Rupp, R., A. Hernandez, and B. A. Mallard. 2007. Association of bovine leukocyte antigen BoLA-DRB3.2 with immune response, mastitis, and production and type traits in Canadian Holsteins. J. Dairy Sci. 90:1029-1038.

Schukken, Y. H., G. J. Bennett, M. J. Zurakowski, H. L. Sharkey, B. J. Rauch, M. J. Thomas, B. Ceglowski, R. L. Saltman, N. Belomestnykh, and R. N. Zadoks. 2011. Randomized clinical trial to evaluate the efficacy of a 5-day ceftiofur hydrochloride intramammary treatment on nonsevere gram-negative clinical mastitis. J. Dairy Sci. 94:6203-6215.

Selsted, M. E., Y. Q. Tang, W. L. Morris, P. A. McGuire, M. J. Novotny, W. Smith, A. H. Henschen, and J. S. Cullor. 1993. Purification, primary structures, and antibacterial activities of beta-defensins, a new family of antimicrobial peptides from bovine neutrophils. J. Biol. Chem. 268:6641-6648.

Shabat, S. K. B., G. Sasson, A. Doron-Faigenboim, T. Durman, S. Yaacoby, M. E. B. Miller, B. A. White, N. Shterzer, and I. Mizrahi. 2016. Specific microbiome-dependent mechanisms underlie the energy harvest efficiency of ruminants. ISME J. 10:2958-2972.

Sharif, S., B. A. Mallard, B. N. Wilkie, J. M. Sargeant, H. M. Scott, J C. M. Dekkers, and K. E. Leslie. 1998. Associations of the bovine major histocompatibility complex DRB3 (BoLA-DRB3) alleles with occurrence of disease and milk somatic cell score in Canadian dairy cattle. Anim. Genet. 29:185-193.

Slettbakk, T., A. Jørstad, T. B. Farver, and J. C. Holmes. 1995. Impact of milking characteristics and morphology of udder and teats on clinical mastitis in first- and second-lactation Norwegian cattle. Prev. Vet. Med. 24:235-244.

Smith, K. L., J. Hogan, and W. Weiss. 1997. Dietary vitamin E and selenium affect mastitis and milk quality. J. Anim. Sci. 75:16591665 .

Sordillo, L. M. 2005. Factors affecting mammary gland immunity and mastitis susceptibility. Livest. Prod. Sci. 98:89-99.

Sordillo, L. M. 2013. Selenium-dependent regulation of oxidative stress and immunity in periparturient dairy cattle. Vet. Med. Int. 2013:154045

Sordillo, L. M., K. Shafer-Weaver, and D. DeRosa. 1997. Immunobiology of the mammary gland. J. Dairy Sci. 80:1851-1865.

Sordillo, L. M., and K. L. Streicher. 2002. Mammary gland immunity and mastitis susceptibility. J. Mammary Gland Biol. Neoplasia 7:135-146.
Spears, J. W., and W. P. Weiss. 2008. Role of antioxidants and trace elements in health and immunity of transition dairy cows. Vet. J. 176:70-76

Starkenburg, R. J., L. B. Hansen, M. E. Kehrli, and H. Chester-Jones. 1997. Frequencies and effects of alternative DRB3.2 alleles of bovine lymphocyte antigen for Holsteins in milk selection and control lines1. J. Dairy Sci. 80:3411-3419.

Stelwagen, K., E. Carpenter, B. Haigh, A. Hodgkinson, and T. T. Wheeler. 2009. Immune components of bovine colostrum and milk. J. Anim. Sci. 87:3-9.

Streeter, R. N., G. Hoffsis, S. Bech-Nielsen, W. Shulaw, and D. Rings. 1995. Isolation of Mycobacterium paratuberculosis from colostrum and milk of subclinically infected cows. Am. J. Vet. Res. 56:13221324

Suojala, L., L. Kaartinen, and S. Pyörälä. 2013. Treatment for bovine Escherichia coli mastitis-An evidence-based approach. J. Vet. Pharmacol. Ther. 36:521-531.

Supré, K., F. Haesebrouck, R. N. Zadoks, M. Vaneechoutte, S. Piepers, and S. De Vliegher. 2011. Some coagulase-negative Staphylococcus species affect udder health more than others. J. Dairy Sci. 94:2329-2340

Suriyasathaporn, W., C. Heuer, E. N. Noordhuizen-Stassen, and Y. H. Schukken. 2000. Hyperketonemia and the impairment of udder defense: A review. Vet. Res. 31:397-412.

Sweeney, R. W. 1996. Transmission of paratuberculosis. Vet. Clin. North Am. Food Anim. Pract. 12:305-312.

Sweeney, R. W., R. H. Whitlock, and A. E. Rosenberger. 1992. Mycobacterium paratuberculosis cultured from milk and supramammary lymph nodes of infected asymptomatic cows. J. Clin. Microbiol. 30:166-171.

Takeshima, S. N., and Y. Aida. 2006. Structure, function and disease susceptibility of the bovine major histocompatibility complex. Anim. Sci. J. 77:138-150.

Takeshima, S. N., Y. Nakai, M. Ohta, and Y. Aida. 2002. Characterization of DRB3 alleles in the MHC of Japanese Shorthorn Cattle by polymerase chain reaction-sequence-based typing. J. Dairy Sci. 85:1630-1632.

Tamilselvam, B., R. A. Almeida, J. R. Dunlap, and S. P. Oliver. 2006. Streptococcus uberis internalizes and persists in bovine mammary epithelial cells. Microb. Pathog. 40:279-285.

Tang, K. L., N. P. Caffrey, D. B. Nóbrega, S. C. Cork, P. E. Ronksley, H. W. Barkema, A. J. Polachek, H. Ganshorn, N. Sharma, J. D Kellner, and W. A. Ghali. 2017. Restricting the use of antibiotics in food-producing animals and its associations with antibiotic resistance in food-producing animals and human beings: A systematic review and meta-analysis. Lancet Planet. Health 1:e316-e327.

Tao, N. E. DePeters, J. B. German, R. Grimm, and C. B. Lebrilla 2009. Variations in bovine milk oligosaccharides during early and middle lactation stages analyzed by high-performance liquid chromatography-chip/mass spectrometry. J. Dairy Sci. 92:2991-3001.

Taponen, S., J. Björkroth, and S. Pyörälä. 2008. Coagulase-negative staphylococci isolated from bovine extramammary sites and intramammary infections in a single dairy herd. J. Dairy Res. 75:422429.

Tappel, A. 1984. Selenium-glutathione peroxidase: Properties and synthesis. Curr. Top. Cell. Regul. 24:87-97.

Tenhagen, B. A., G. Köster, J. Wallmann, and W. Heuwieser. 2006. Prevalence of mastitis pathogens and their resistance against antimicrobial agents in dairy cows in Brandenburg, Germany. J. Dairy Sci. 89:2542-2551.

Thorberg, B. M., M. L. Danielsson-Tham, U. Emanuelson, and K. P. Waller. 2009. Bovine subclinical mastitis caused by different types of coagulase-negative staphylococci. J. Dairy Sci. 92:4962-4970.

Toivanen, P., J. Vaahtovuo, and E. Eerola. 2001. Influence of major histocompatibility complex on bacterial composition of fecal flora. Infect. Immun. 69:2372-2377.

Tolle, A. 1980. The microflora of the udder. Factors influencing the bacteriological quality of raw milk. International Dairy Federation Bulletin Document 120:4. 
Vanderhaeghen, W., S. Piepers, F. Leroy, E. Van Coillie, F. Haesebrouck, and S. De Vliegher. 2014. Invited review: Effect, persistence, and virulence of coagulase-negative Staphylococcus species associated with ruminant udder health. J. Dairy Sci. 97:5275-5293.

van Eijk, M. J. T., J. A. Stewart-Haynes, and H. A. Lewin. 1992. Extensive polymorphism of the BOLA-DRB3 gene distinguished by PCR-RFLP. Anim. Genet. 23:483-496.

Vazquez-Torres, A., J. Jones-Carson, A. J. Bäumler, S. Falkow, R. Valdivia, W. Brown, M. Le, R. Berggren, W. T. Parks, and F. C. Fang. 1999. Extraintestinal dissemination of Salmonella by CD18expressing phagocytes. Nature 401:804.

Verdier-Metz, I., G. Gagne, S. Bornes, F. Monsallier, P. Veisseire, C. Delbès-Paus, and M. C. Montel. 2012. Cow teat skin, a potential source of diverse microbial populations for cheese production. Appl. Environ. Microbiol. 78:326-333.

Waller, K. P. 2002. Mammary gland immunology around parturition. Pages 231-245 in Biology of the Mammary Gland. Springer, New York, NY.

Wang, X., X. Li, C. Zhao, P. Hu, H. Chen, Z. Liu, G. Liu, and Z. Wang. 2012. Correlation between composition of the bacterial community and concentration of volatile fatty acids in the rumen during the transition period and ketosis in dairy cows. Appl. Environ. Microbiol. 78:2386-2392.

Weber, P. S., T. Toelboell, L. C. Chang, J. D. Tirrell, P. M. Saama, G. W. Smith, and J. L. Burton. 2004. Mechanisms of glucocorticoid-induced down-regulation of neutrophil L-selectin in cattle: Evidence for effects at the gene-expression level and primarily on blood neutrophils. J. Leukoc. Biol. 75:815-827.

Weiss, W. P., J. S. Hogan, K. L. Smith, and K. H. Hoblet. 1990. Relationships among selenium, vitamin $\mathrm{E}$, and mammary gland health in commercial dairy herds. J. Dairy Sci. 73:381-390.
Whist, A. C., O. Østerås, and L. Sølverød. 2006. Clinical mastitis in Norwegian herds after a combined selective dry-cow therapy and teat-dipping trial. J. Dairy Sci. 89:4649-4659.

Wilson, D. J., R. N. Gonzalez, K. L. Case, L. L. Garrison, and Y. T. Groöhn. 1999. Comparison of seven antibiotic treatments with no treatment for bacteriological efficacy against bovine mastitis pathogens. J. Dairy Sci. 82:1664-1670.

Woodward, W. D., T. E. Besser, A. C. Ward, and L. B. Corbeil. 1987. In vitro growth inhibition of mastitis pathogens by bovine teat skin normal flora. Can. J. Vet. Res. 51:27-31.

Young, W. B. C. Hine, O. A. Wallace, M. Callaghan, and R. Bibiloni. 2015. Transfer of intestinal bacterial components to mammary secretions in the cow. PeerJ 3:e888.

Zadoks, R. N., H. G. Allore, H. W. Barkema, O. C. Sampimon, G. J. Wellenberg, Y. T. Gröhn, and Y. H. Schukken. 2001. Cow- and quarter-level risk factors for Streptococcus uberis and Staphylococcus aureus mastitis. J. Dairy Sci. 84:2649-2663.

Zadoks, R. N., J. R. Middleton, S. McDougall, J. Katholm, and Y. H. Schukken. 2011. Molecular epidemiology of mastitis pathogens of dairy cattle and comparative relevance to humans. J. Mammary Gland Biol. Neoplasia 16:357-372.

Zerbe, H., N. Schneider, W. Leibold, T. Wensing, T. A. M. Kruip, and H. J. Schuberth. 2000. Altered functional and immunophenotypical properties of neutrophilic granulocytes in postpartum cows associated with fatty liver. Theriogenology 54:771-786.

Zhang, R., W. Huo, W. Zhu, and S. Mao. 2015. Characterization of bacterial community of raw milk from dairy cows during subacute ruminal acidosis challenge by high-throughput sequencing. J. Sci. Food Agric. 95:1072-1079. 